Federal Reserve Bank of Minneapolis

Research Department Staff Report 500

Revised November 2014

\title{
The Cost of Financial Frictions for Life Insurers*
}

\author{
Ralph S.J. Koijen \\ London Business School \\ Motohiro Yogo \\ Federal Reserve Bank of Minneapolis
}

\begin{abstract}
During the financial crisis, life insurers sold long-term policies at deep discounts relative to actuarial value. The average markup was as low as -19 percent for annuities and -57 percent for life insurance. This extraordinary pricing behavior was due to financial and product market frictions, interacting with statutory reserve regulation that allowed life insurers to record far less than a dollar of reserve per dollar of future insurance liability. We identify the shadow cost of capital through exogenous variation in required reserves across different types of policies. The shadow cost was \$0.96 per dollar of statutory capital for the average company in November 2008.
\end{abstract}

Keywords: Annuities; Capital regulation; Financial crisis; Leverage; Life insurance JEL classification: G01, G22, G28

*Koijen: rkoijen@london.edu; Yogo: yogo@minneapolisfed.org. A.M. Best Company, WebAnnuities Insurance Agency, and Compulife Software own the copyright to their respective data, which we use with permission. We thank Mary Anomalay, Jahiz Barlas, Minsoo Kim, Peter Nebres, and Julia Pei for assistance in putting together the data on annuity and life insurance prices. For comments and discussions, we thank three referees, Jennie Bai, Jeffrey Brown, Itamar Drechsler, Kenneth Froot, Stefano Giglio, Victoria Ivashina, Arvind Krishnamurthy, Zain MoheyDeen, Luboš Pástor, Anna Paulson, Michael Roberts, David Scharfstein, Amir Sufi, and Annette Vissing-Jørgensen. We also thank seminar participants at Aalto University; Copenhagen Business School; Emory University; Erasmus University; Federal Reserve Bank of Atlanta, Boston, Chicago, Kansas City, Minneapolis, New York, and San Francisco; Harvard University; London Business School; MIT; Northwestern University; Norwegian Business School; Oxford University; Princeton University; Stanford University; Tilburg University; University of British Columbia, Chicago, Hong Kong, Houston, Melbourne, Minnesota, New South Wales, Sydney, Technology Sydney, Tokyo, Washington, and Wisconsin; UCLA; UCSD; 2012 SED Annual Meeting; 2012 NBER Summer Institute Capital Markets and the Economy Workshop; 2012 System Committee Meeting on Financial Structure and Regulation; 2012 Wharton Conference on Liquidity and Financial Crises; 2012 NBER Public Economics Program Meeting; 2012 Boston University/Boston Fed Conference on Macro-Finance Linkages; 2013 Utah Winter Finance Conference; 2013 NBER Insurance Working Group Meeting; 2013 Shanghai Macroeconomics Workshop; 2013 EFA Annual Meeting; and 2014 AFA Annual Meeting. The authors declare that they have no relevant or material financial interests that relate to the research described in this paper. The views expressed herein are those of the authors and not necessarily those of the Federal Reserve Bank of Minneapolis or the Federal Reserve System. 
Traditional theories of insurance markets assume that insurance companies operate in an efficient capital market and supply policies at actuarially fair prices. Consequently, the market equilibrium is primarily determined by the demand side, either by life-cycle demand (Yaari 1965) or by informational frictions (Rothschild and Stiglitz 1976). In contrast to these traditional theories, we find that the pricing behavior of these financial institutions is significantly affected by financial frictions as well as product market frictions that lead to a price war.

Our key finding is that life insurers reduced the price of long-term policies from November 2008 to February 2009, when falling interest rates implied that they should have instead raised prices. The average markup, relative to actuarial value (i.e., the present value of future insurance liabilities), was -16 percent for 30-year term annuities and -19 percent for life annuities at age 60. Similarly, the average markup was -57 percent for universal life insurance at age 30. This pricing behavior contrasts sharply with the 6 to 10 percent markup that life insurers earn in ordinary times (Mitchell et al. 1999). In the cross section of policies, the price reductions were larger for those policies with looser statutory reserve requirements. In the cross section of insurance companies, the price reductions were larger for those companies that suffered larger balance sheet shocks (i.e., lower asset growth, higher leverage, and larger deficit in risk-based capital).

This extraordinary pricing behavior coincided with two unusual circumstances. First, the financial crisis had an adverse impact on insurance companies' balance sheets, especially those companies with large deferred (fixed and variable) annuity liabilities whose guarantees (i.e., embedded put options) turned out to be unprofitable. Second, statutory reserve regulation in the United States allowed life insurers to record far less than a dollar of reserve per dollar of future insurance liability around December 2008. This allowed life insurers to generate accounting profits by selling policies at a price far below actuarial value, as long as that price was above the reserve value. Insurance companies care about accounting profits insofar as it increases statutory capital (i.e., assets relative to accounting liabilities), which is an important metric of capital adequacy for rating agencies and state regulators.

We develop a model of optimal insurance pricing to show that the extraordinary pricing behavior implies a high shadow value of statutory capital. In our model, an insurance company sets prices for various types of policies to maximize the present value of profits, subject to both financial and product market frictions. Financial frictions enter as a leverage constraint on statutory capital, which captures the fact that insurance companies are rated and regulated because of their incentives for excessive risk taking (i.e., moral hazard). Product market frictions enter through search frictions that make future demand increasing in statutory capital (e.g., through higher ratings). The insurance company may reduce prices, 
even below actuarial value, either to relax its leverage constraint or to boost future demand. The shadow cost of capital embeds both financial and product market frictions, which are not separately identified by the first-order conditions of the model.

We estimate the shadow cost of capital using panel data on the pricing of term annuities, life annuities, and universal life insurance, which are merged with the financial statements of the insurance companies. Relative to other industries, life insurance presents a unique opportunity to identify the shadow cost for two reasons. First, life insurers sell relatively simple products whose marginal cost can be accurately measured. Second, statutory reserve regulation specifies a constant discount rate for reserve valuation, regardless of the maturity of the policy. This mechanical rule generates exogenous variation in required reserves across policies of different maturities, which acts as relative shifts in the supply curve that are plausibly exogenous.

We find that the shadow cost of capital was $\$ 0.96$ per dollar of statutory capital for the average company in November 2008. This cost varies from $\$ 0.10$ to $\$ 5.53$ per dollar of statutory capital for the cross section of insurance companies in our sample. Those companies with higher shadow cost sold more policies while reducing prices, consistent with a downward shift in the supply curve. In addition, those companies with higher shadow cost raised or retained more capital, through capital injections from their holding companies and reduction of stockholder dividends. Many of the holding companies in our sample appear constrained during the financial crisis, as evidenced by application for government assistance such as the Troubled Asset Relief Program, issuance of public equity, or suspension of dividends. Hence, capital injections from these holding companies to their insurance subsidiaries could have been limited by frictions in external capital markets. However, we cannot conclusively rule out a price war arising from product market frictions as an alternative explanation.

We rule out default risk as an alternative explanation for several reasons. First, the markups on term annuities are too low to be justified by default risk, given reasonable assumptions about the recovery rate. Second, the term structure of risk-neutral default probabilities implied by term annuities does not match that implied by credit default swaps in magnitude, slope across maturity, or variation across insurance companies. Finally, the absence of discounts on life annuities during the Great Depression serves as out-of-sample evidence against default risk as a sole explanation.

The extraordinary pricing of liabilities complements related evidence on the asset side of the balance sheet during the financial crisis. Financially constrained life insurers sold corporate bonds with the highest unrealized capital gains, carried at historical cost according to the accounting rules, in order to improve their capital positions (Ellul et al. 2012). They also sold downgraded bonds at fire-sale prices in order to reduce their required capital (Merrill 
et al. 2012). An important difference between our work and the traditional theory of fire sales (Shleifer and Vishny 1992) is that policies are liabilities that insurance companies issue to households, rather than assets that they trade with other institutional investors in the secondary market. In addition, an important advantage of the liability side is that the counterfactual (i.e., pricing in the absence of frictions) can be more accurately measured than the asset side, so that we can better quantify the cost of financial frictions.

Our finding that the supply curve for life insurers shifts down in response to a balance sheet shock, causing prices to fall, contrasts with the evidence that the supply curve for property and casualty insurers shifts up, causing prices to rise (Gron 1994, Froot and O'Connell 1999). Although these findings may seem contradictory at first, they are both consistent with our supply-driven theory of insurance pricing. The key difference between life insurers and property and casualty insurers is their accounting of liabilities under statutory reserve regulation. Life insurers were able to raise statutory capital by selling new policies because their reserve valuation was more aggressive than mark to market during the financial crisis. In contrast, property and casualty insurers must reduce their statutory capital when selling new policies because their reserve valuation is always more conservative than mark to market.

The remainder of the paper is organized as follows. Section I describes our data and documents key facts that motivate our study of insurance prices. Section \reviews aspects of statutory reserve regulation that are relevant to our analysis. In Section III, we develop a model of optimal insurance pricing, based on financial and product market frictions interacting with statutory reserve regulation. In Section [IV, we estimate the shadow cost of capital through the insurance pricing model. Section $\nabla$ discusses the merits and limitations of financial frictions as an explanation for the evidence. In Section VI, we rule out default risk as an alternative explanation. Section VII concludes with broader implications of our study for household finance and macroeconomics.

\section{Annuity and Life Insurance Prices}

\section{A. Data Construction}

Annuity Prices

Our sample of annuity prices is from the WebAnnuities Insurance Agency, which has published quotes from the leading life insurers at a semiannual frequency from January 1989 to July 2011 (Stern 1989-2011) and at a monthly frequency from January 2007 to August 2009 (Stern 2007-2009). Following Mitchell et al. (1999), we focus on single premium immediate annuities in nonqualified accounts (i.e., only the interest is taxable). These policies cannot 
be lapsed because the premium is paid up front as a single lump sum. Our data consist of two types of policies: term and life annuities. For term annuities, we have quotes for 5- to 30-year maturities (every five years in between). For life annuities, we have quotes for "life only" policies without guarantees as well as those with 10- or 20-year guarantees. These quotes are available for both males and females aged 50 to 85 (every five years in between).

A term annuity pays annual income for a fixed maturity of $M$ years. Since term annuities have a fixed income stream that is independent of survival, they are straight bonds rather than longevity insurance. An insurance company that issues a term annuity must buy a portfolio of Treasury bonds to replicate its future cash flows. A portfolio of corporate bonds, for example, does not replicate the cash flows because of default risk. Thus, the law of one price implies that the Treasury yield curve is the appropriate cost of capital for the valuation of term annuities. Let $R_{t}(m)$ be the zero-coupon Treasury yield at maturity $m$ and time $t$. We define the actuarial value of an $M$-year term annuity per dollar of income as

$$
V_{t}(M)=\sum_{m=1}^{M} \frac{1}{R_{t}(m)^{m}}
$$

We calculate the actuarial value for term annuities based on the zero-coupon yield curve for off-the-run Treasury bonds (Gürkaynak, Sack and Wright 2007).

A life annuity with an $M$-year guarantee pays annual income for the first $M$ years regardless of survival, then continues paying income thereafter until the death of the insured. Let $p_{n}$ be the one-year survival probability at age $n$, and let $N$ be the maximum attainable age according to the appropriate mortality table. We define the actuarial value of a life annuity with an $M$-year guarantee at age $n$ per dollar income as

$$
V_{t}(n, M)=\sum_{m=1}^{M} \frac{1}{R_{t}(m)^{m}}+\sum_{m=M+1}^{N-n} \frac{\prod_{l=0}^{m-1} p_{n+l}}{R_{t}(m)^{m}}
$$

We calculate the actuarial value for life annuities based on the appropriate mortality table from the American Society of Actuaries and the zero-coupon Treasury yield curve. We use the 1983 Annuity Mortality Basic Table prior to January 1999 and the 2000 Annuity Mortality Basic Table since January 1999. These mortality tables are derived from the actual mortality experience of insured pools, based on data provided by various companies. Thus, they account for adverse selection in annuity markets, that is, an insured pool of annuitants has higher life expectancy than the overall population. We smooth the transition between the two vintages of the mortality tables by geometric averaging. 


\section{Life Insurance Prices}

Our sample of life insurance prices is from Compulife Software (2005-2011), which is a computer-based quotation system for insurance agents. We focus on guaranteed universal life policies, which are quoted for the leading life insurers since January 2005. These policies have constant guaranteed premiums and accumulate no cash value, so they are essentially "permanent" term life policies 1 We pull quotes for all US states for the regular health category and a face amount of $\$ 250,000$. We focus on males and females aged 30 to 80 (every ten years in between).

Universal life insurance pays out a death benefit upon the death of the insured. The policy is in effect as long as the policyholder pays an annual premium while the insured is alive. We define the actuarial value of universal life insurance at age $n$ per dollar of death benefit as

$$
V_{t}(n)=\left(1+\sum_{m=1}^{N-n-1} \frac{\prod_{l=0}^{m-1} p_{n+l}}{R_{t}(m)^{m}}\right)^{-1}\left(\sum_{m=1}^{N-n} \frac{\prod_{l=0}^{m-2} p_{n+l}\left(1-p_{n+m-1}\right)}{R_{t}(m)^{m}}\right) .
$$

This formula does not account for the potential lapsation of policies, that is, the policyholder may drop coverage prior to the death of the insured. There is currently no agreed-upon standard for lapsation pricing, partly because lapsations are difficult to model and predict. Although some companies price in low levels of lapsation, others take the conservative approach of assuming no lapsation in life insurance valuation.

We calculate the actuarial value for life insurance based on the appropriate mortality table from the American Society of Actuaries and the zero-coupon Treasury yield curve. We use the 2001 Valuation Basic Table prior to January 2008 and the 2008 Valuation Basic Table since January 2008. These mortality tables are derived from the actual mortality experience of insured pools, so they account for adverse selection in life insurance markets. We smooth the transition between the two vintages of the mortality tables by geometric averaging.

\section{Financial Statements and Ratings Information}

The annual financial statements and ratings information are from A.M. Best Company (19932012a) for fiscal years 1992 to 2011, which is merged with A.M. Best Company (1999-2012b) for fiscal years 1998 to 2011. These financial statements are prepared according to the statutory accounting principles and filed with the National Association of Insurance Commis-

\footnotetext{
${ }^{1}$ Although Compulife has quotes for various types of policies from annual renewable to 30-year term life policies, they are not useful for our purposes. A term life policy typically has a renewal option at the end of the guaranteed term. Because the premiums under the renewal option vary across insurance companies, cross-sectional price comparisons are difficult and imprecise.
} 
sioners. Throughout the paper, we use a measure of accounting equity that is relevant for risk-based capital (A.M. Best Company 2004, p. 11), which is capital and surplus plus asset valuation reserve and conditional reserves. We define the following variables for our analysis:

- Log assets: Logarithm of total admitted assets.

- Asset growth: Growth rate of total admitted assets.

- Leverage ratio: One minus the ratio of equity to total admitted assets.

- Risk-based capital relative to guideline: Best's Capital Adequacy Ratio minus the guideline for the current rating (A.M. Best Company 2011, p. 24).

- Net equity inflow: Ratio of capital and surplus paid in minus stockholder dividends to previous equity.

We merge annuity and life insurance prices in a given fiscal year with the financial statements at fiscal year-end. Although we have the financial statements for all companies, our sample is ultimately limited by the availability of historical data on annuity and life insurance prices. Our data sources, WebAnnuities Insurance Agency and Compulife Software, draw from the larger companies in the industry with an A.M. Best rating of $\mathrm{A}-$ or higher and agency- or broker-based marketing (as opposed to direct sales). Table 1 summarizes our sample of insurance companies for fiscal years 1998 to 2011. In 2011, our sample covers 47 of 275 companies with an A.M. Best rating of A- or higher and agency- or broker-based marketing. These companies represented 61 percent of the immediate annuity market and 42 percent of the life insurance market. Across all years, our sample covers 101 of 489 companies.

\section{B. Summary Statistics}

Table 2 summarizes our data on annuity and life insurance prices. We have 870 semiannual observations on 10-year term annuities from January 1989 to July 2011. The markup, defined as the percent deviation of the quoted price from actuarial value, has a mean of 7.0 percent and a median of 7.2 percent. We can rule out adverse selection as a source of this markup because term annuities are essentially straight bonds. Instead, the markup must be attributed to marketing and administrative costs as well as economic profits that could arise from imperfect competition. The fact that the average markup on term annuities falls in maturity is consistent with the presence of fixed costs. The price of 10-year term annuities varies significantly across insurance companies, summarized by a standard deviation of 4.2 percent. Mitchell et al. (1999) find similar variation for life annuities. 
We have 13,675 monthly observations on life annuities from January 1989 to July 2011. The average markup is 7.9 percent with a standard deviation of 7.6 percent. The pricing data on life annuities with guarantees are available since May 1998. For 10-year guaranteed annuities, the average markup is 4.2 percent with a standard deviation of 6.7 percent. For 20-year guaranteed annuities, the average markup is 4.5 percent with a standard deviation of 6.5 percent.

We have 31,226 monthly observations on universal life insurance from January 2005 to July 2011. The average markup is -5.8 percent with a standard deviation of 16.0 percent. The negative average markup does not mean that insurance companies lose money on these policies. With a constant premium and a rising mortality rate, policyholders are essentially prepaying for coverage later in life. When a life insurance policy is lapsed, the insurance company earns a windfall profit because the present value of the remaining premiums is typically less than the present value of the future death benefit. Since there is currently no agreed-upon standard for lapsation pricing, our calculation of actuarial value does not account for lapsation. We are not especially concerned that the average markup might be slightly mismeasured because our analysis focuses on the variation in markups over time and across policies of different maturities.

Table 2 shows that the data on the full cross section of annuity prices are available only since May 1998. Therefore, we construct our main estimation sample in Section IV based on the data from May 1998 to July 2011, which yields a total of 45,430 observations on annuity and life insurance prices.

\section{Extraordinary Pricing Behavior}

Figure1 1reports the time series of the average markup on term annuities at various maturities, averaged across insurance companies and reported with a 95 percent confidence interval. The average markup usually varies between 0 and 10 percent, except around November 2008. The time-series variation in the average markup implies that insurance companies do not change annuity prices to perfectly offset interest-rate movements (Charupat, Kamstra and Milevsky 2012).

For 30-year term annuities, the average markup fell to an extraordinary -15.7 percent in November 2008. Much of this large negative markup arises from reductions in the price of term annuities from May 2007 to November 2008, as we discuss below. In November 2008, the magnitude of the average markup is monotonically related to the maturity of the term annuity. The average markup was -8.5 percent for 20 -year, -4.0 percent for 10 -year, and -1.1 percent for 5-year term annuities. Excluding the extraordinary period around November 2008, the average markup was negative for 30-year term annuities only twice 
before in our semiannual sample, in October 2000 and October 2001.

Figure 2 reports the time series of the average markup on life annuities for males at various ages. Our findings are similar to those for term annuities. For life annuities at age 60, the average markup fell to an extraordinary -19.0 percent in December 2008. The magnitude of the average markup is monotonically related to age, which is negatively related to effective maturity. The average markup on life annuities was -14.7 percent at age 65 , -10.3 percent at age 70 , and -5.7 percent at age 75.2

Figure 3 reports the time series of the average markup on universal life insurance for males at various ages. Our findings are similar to those for term and life annuities. For universal life insurance at age 30, the average markup fell to an extraordinary -57.0 in December 2008. The magnitude of the average markup is monotonically related to age. The average markup on universal life insurance was -50.2 percent at age $40,-42.1$ percent at age 50 , and -27.5 percent at age 60 .

Figure 4 shows the cross-sectional relation between changes in annuity prices from May 2007 to November 2008 and four measures of balance sheet shocks at fiscal year-end 2008. The figure reveals two interesting facts. First, most of the insurance companies reduced prices during this period, which is remarkable given that falling interest rates implied rising actuarial value. Second, the price reductions were larger for those companies with lower asset growth, higher leverage ratio, lower risk-based capital relative to guideline, and higher ratio of deferred annuity liabilities to equity. Deferred annuity liabilities, whose guarantees were unprofitable during the financial crisis, were an important source of balance sheet shocks for those companies that were active in this market.

The fact that the price reductions were larger for those companies that suffered larger balance sheet shocks raises financial frictions as a potential explanation for the evidence. However, the fact that even relatively unaffected companies reduced or kept prices constant suggests that there are other important forces, such as product market frictions that lead to a price war. The rest of the paper examines financial and product market frictions as potential explanations for the evidence.

\section{Statutory Reserve Regulation for Life Insurers}

When an insurance company sells an annuity or life insurance policy, its assets increase by the purchase price of the policy. At the same time, the insurance company must record statutory

\footnotetext{
${ }^{2}$ In Appendix D, we estimate the average markup on life annuities relative to an alternative measure of actuarial value based on the US agency yield curve. We find that the average markup remains negative in December 2008, under this conservative adjustment for the special status of Treasury bonds as collateral in financial transactions.
} 
reserves on the liability side of its balance sheet to cover future insurance liabilities. In the United States, the amount of required reserves for each type of policy is governed by state law, but all states essentially follow recommended guidelines known as Standard Valuation Law (National Association of Insurance Commissioners 2011, Appendix A-820). Standard Valuation Law establishes mortality tables and discount rates that are to be used for reserve valuation.

In this section, we review the reserve valuation rules for annuities and life insurance. Because these policies essentially have no exposure to market risk, finance theory implies that the market value of these policies is determined by the term structure of riskless interest rates. However, Standard Valuation Law requires that the reserve value of these policies be calculated using a mechanical discount rate that is a function of the Moody's composite yield on seasoned corporate bonds 3 Insurance companies care about the reserve value of policies insofar as it is used by rating agencies and state regulators to determine the adequacy of statutory reserves (A.M. Best Company 2011, p. 31). A rating agency could downgrade an insurance company whose asset value has fallen relative to its statutory reserves 4 In the extreme case, the state regulator could liquidate an insurance company whose assets are deficient relative to its statutory reserves.

\section{A. Term Annuities}

Let $y_{t}$ be the 12-month moving average of the Moody's composite yield on seasoned corporate bonds, over the period ending on June 30 of the issuance year of the policy. For an annuity issued in month $t$, Standard Valuation Law specifies the following discount rate for reserve valuation:

$$
\widehat{R}_{t}-1=0.03+0.8\left(y_{t}-0.03\right)
$$

which is rounded to the nearest 25 basis point. This is a constant discount rate that applies to all expected liabilities, regardless of maturity. The exogenous variation in required reserves that this mechanical rule generates, both over time and across policies of different maturities, will allow us to identify the shadow cost of capital.

Figure 5 reports the time series of the discount rate for annuities, together with the 10year zero-coupon Treasury yield. The discount rate for annuities has generally fallen over the

\footnotetext{
${ }^{3}$ The same discount rate is used for financial reporting at the holding company level, prepared according to generally accepted accounting principles (GAAP). The key difference of GAAP, compared with statutory accounting principles, is the deferral and amortization of initial acquisition costs, which tends to increase reported equity (Lombardi 2006, pp. 4-7).

${ }^{4}$ For example, A.M. Best Company (2009) reports that MetLife's "financial leverage is at the high end of its threshold for the current rating level" at fiscal year-end 2008.
} 
last 20 years as nominal interest rates have fallen. However, the discount rate for annuities has fallen more slowly than the 10-year Treasury yield. This means that statutory reserve requirements for annuities have become looser over time because a high discount rate implies low reserve valuation.

The reserve value of an $M$-year term annuity per dollar of income is

$$
\widehat{V}_{t}(M)=\sum_{m=1}^{M} \frac{1}{\widehat{R}_{t}^{m}}
$$

Figure 6 reports the ratio of reserve to actuarial value for term annuities (i.e., $\widehat{V}_{t}(M) / V_{t}(M)$ ) at maturities of 5 to 30 years. Whenever this ratio is equal to one, the insurance liabilities are marked to market. That is, the insurance company records a dollar of reserve per dollar of future insurance liabilities in present value. Whenever this ratio is above one, the reserve valuation is more conservative than mark to market. Conversely, whenever this ratio is below one, the reserve valuation is more aggressive than mark to market.

For 30-year term annuities, the ratio of reserve to actuarial value reaches a peak of 1.20 in November 1994 and a trough of 0.73 in January 2009. If an insurance company were to sell a 30-year term annuity at actuarial value in November 1994, its statutory reserves would increase by $\$ 1.20$ per dollar of policies sold. This implies a loss of $\$ 0.20$ in accounting equity per dollar of policies sold. In contrast, if an insurance company were to sell a 30-year term annuity at actuarial value in January 2009, its statutory reserves would only increase by $\$ 0.73$ per dollar of policies sold. This implies a gain of $\$ 0.27$ in accounting equity per dollar of policies sold.

\section{B. Life Annuities}

The reserve valuation of life annuities requires mortality tables. The American Society of Actuaries produces two versions of mortality tables, which are called basic and loaded. The loaded tables, which are used for reserve valuation, are conservative versions of the basic tables that underestimate the mortality rates. The loaded tables ensure that insurance companies have adequate reserves, even if actual mortality rates turn out to be lower than those projected by the basic tables. For calculating the reserve value, we use the 1983

Annuity Mortality Table prior to January 1999 and the 2000 Annuity Mortality Table since January 1999.

Let $\widehat{p}_{n}$ be the one-year survival probability at age $n$, and let $N$ be the maximum attainable age according to the appropriate loaded mortality table. The reserve value of a life annuity 
with an $M$-year guarantee at age $n$ per dollar of income (Lombardi 2006, p. 204) is

$$
\widehat{V}_{t}(n, M)=\sum_{m=1}^{M} \frac{1}{\widehat{R}_{t}^{m}}+\sum_{m=M+1}^{N-n} \frac{\prod_{l=0}^{m-1} \widehat{p}_{n+l}}{\widehat{R}_{t}^{m}}
$$

where the discount rate is given by equation (44).

Figure 6 also reports the ratio of reserve to actuarial value for life annuities and 10-year guaranteed annuities for males aged 50 to 80 (every ten years in between). The time-series variation in reserve to actuarial value for life annuities is quite similar to that for term annuities. In particular, the ratio reaches a peak in November 1994 and a trough in January 2009. Since the reserve valuation of term annuities depends only on the discount rates, the similarity to term annuities implies that discount rates, rather than mortality tables, have a predominant effect on the reserve valuation of life annuities.

\section{Life Insurance}

Let $y_{t}$ be the minimum of the 12-month and the 36-month moving average of the Moody's composite yield on seasoned corporate bonds, over the period ending on June 30 of the year prior to issuance of the policy. For life insurance with guaranteed term greater than 20 years issued in month $t$, Standard Valuation Law specifies the following discount rate for reserve valuation:

$$
\widehat{R}_{t}-1=0.03+0.35\left(\min \left\{y_{t}, 0.09\right\}-0.03\right)+0.175\left(\max \left\{y_{t}, 0.09\right\}-0.09\right),
$$

which is rounded to the nearest 25 basis point.

As with life annuities, the American Society of Actuaries produces basic and loaded mortality tables for life insurance. The loaded tables, which are used for reserve valuation, are conservative versions of the basic tables that overestimate the mortality rates. For calculating the reserve value, we use the 2001 Commissioners Standard Ordinary Mortality Table. The reserve value of life insurance at age $n$ per dollar of death benefit (Lombardi 2006, pp. 67-68) is

$$
\widehat{V}_{t}(n)=\left(1+\sum_{m=1}^{N-n-1} \frac{\prod_{l=0}^{m-1} \widehat{p}_{n+l}}{\widehat{R}_{t}^{m}}\right)^{-1}\left(\sum_{m=1}^{N-n} \frac{\prod_{l=0}^{m-2} \widehat{p}_{n+l}\left(1-\widehat{p}_{n+m-1}\right)}{\widehat{R}_{t}^{m}}\right)-\frac{1-\widehat{p}_{n}}{\widehat{R}_{t}}
$$

Finally, Figure 6 reports the ratio of reserve to actuarial value for universal life insurance for males aged 30 to 60 (every ten years in between). Our earlier caveat regarding lapsation applies to this figure as well, so that we focus on the variation in reserve to actuarial value 
over time and across policies of different maturities. The reserve value falls significantly relative to actuarial value around December 2008. As shown in Figure 5, this is caused by the fact that the discount rate for life insurance stays constant during this period, while the 10-year Treasury yield falls significantly. If an insurance company were to sell universal life insurance to a 30-year-old male in December 2008, its statutory reserves would only increase by $\$ 0.69$ per dollar of policies sold. This implies a gain of $\$ 0.31$ in accounting equity per dollar of policies sold.

\section{Insurance Pricing under Financial and Product Market Frictions}

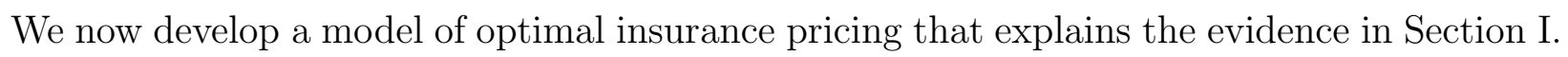
In our model, an insurance company sets prices for various types of policies to maximize the present value of profits, subject to both financial and product market frictions. Financial frictions enter through a leverage constraint on statutory capital, or the value of assets relative to statutory reserves (Gron 1990, Winter 1994). Product market frictions enter through search frictions that make future demand increasing in statutory capital (e.g., through higher ratings). The insurance company may reduce prices, even below actuarial value, either to relax its leverage constraint or to boost future demand. The model shows that financial and product market frictions are not separately identified by the first-order conditions for insurance pricing.

\section{A. Insurance Company's Maximization Problem}

Balance Sheet Dynamics

We first describe how the sale of new policies affects an insurance company's balance sheet, which will allow us to introduce both financial and product market frictions. The insurance company sells $Q_{i, t}$ policies of type $i=1, \ldots, I$ in period $t$ at the price $P_{i, t}$. The different types of policies include annuities and life insurance, which are differentiated not only by maturity but also by sex and age of the insured. The insurance company incurs a fixed (marketing and administrative) cost $C_{t}$ in each period.

Let $A_{t-1}$ be the insurance company's assets at the beginning of period $t$, and let $R_{t}$ be an exogenous return on its assets in period $t$. Its assets at the end of period $t$, after the sale of new policies, is

$$
A_{t}=R_{t} A_{t-1}+\sum_{i=1}^{I} P_{i, t} Q_{i, t}-C_{t}
$$


As discussed in Section III, the insurance company must also record statutory reserves on the liability side of its balance sheet. Let $L_{t-1}$ be its statutory reserves at the beginning of period $t$, and let $R_{t}$ be an exogenous return on its statutory reserves in period $t$. Let $\widehat{V}_{i, t}$ be the reserve value of policy $i$ in period $t$. Its statutory reserves at the end of period $t$, after the sale of new policies, is

$$
L_{t}=R_{t} L_{t-1}+\sum_{i=1}^{I} \widehat{V}_{i, t} Q_{i, t}
$$

We define the insurance company's statutory capital as the value of its assets relative to statutory reserves:

$$
K_{t}=A_{t}-\phi^{-1} L_{t}
$$

where $\phi \leq 1$ is a constant. Equations (9) and (10) imply that the law of motion for statutory capital is

$$
K_{t}=R_{t} K_{t-1}+\sum_{i=1}^{I}\left(P_{i, t}-\phi^{-1} \widehat{V}_{i, t}\right) Q_{i, t}-C_{t}
$$

\section{Financial Frictions}

The insurance company faces a leverage constraint:

$$
\frac{L_{t}}{A_{t}} \leq \phi \Longleftrightarrow K_{t} \geq 0
$$

where $\phi$ is the maximum leverage ratio. This constraint can also be motivated as a simple version of a risk-based capital constraint:

$$
\frac{A_{t}-L_{t}}{\rho L_{t}} \geq \psi
$$

where $\rho$ is the risk charge and $\psi$ is the guideline for a rating or regulatory action 5 Note that equations (13) and (14) are equivalent when $\phi^{-1}=1+\rho \psi$. At a deeper level, the leverage constraint captures financial frictions that arise from the incentives to take excessive risk due to the presence of state guaranty funds or other agency problems.

In the model that is presented here, financial frictions enter as a hard constraint instead

\footnotetext{
${ }^{5}$ For example, A.M. Best Company (2004) specifies $\rho \in[0.75 \%, 3.5 \%]$ for interest-rate risk on general account annuities and $\psi=160 \%$ as the guideline for an $\mathrm{A}+$ rating.
} 
of a continuous cost function. In Appendix B, we show that an alternative model in which the insurance company faces a continuous cost on shortfalls in statutory capital has the same implications for optimal insurance pricing.

\section{Product Market Frictions}

For each policy $i$ in period $t$, a mass $m_{i, t}\left(K_{t-1}\right)$ of consumers matches with an insurance company whose statutory capital is $K_{t-1}$ at the end of period $t-1$. Consumers are more likely to match with insurance companies that have higher statutory capital, so that $\partial m_{i, t} / \partial K_{t-1} \geq$ 0 (Hortaçsu and Syverson 2004). The underlying assumption is that ratings, or reputation in the product market more generally, is increasing in statutory capital. Conditional on matching, each consumer demands $q_{i, t}\left(P_{i, t}\right)$ policies at the price $P_{i, t}$, where $\partial q_{i, t} / \partial P_{i, t}<0$. Under these assumptions, the insurance company faces the following demand function:

$$
Q_{i, t}\left(P_{i, t}, K_{t-1}\right)=m_{i, t}\left(K_{t-1}\right) q_{i, t}\left(P_{i, t}\right)
$$

with the properties that $\partial Q_{i, t} / \partial P_{i, t}<0$ and $\partial Q_{i, t} / \partial K_{t-1} \geq 0.6$

An alternative microfoundation for a demand function with the same properties is an insurance market with product differentiation along company characteristics (Anderson, de Palma and Thisse 1992, Chapter 2). Demand increases in statutory capital because, holding price constant, consumers attain higher utility by buying policies from insurance companies with higher statutory capital.

\section{Profits and Firm Value}

Let $V_{i, t}$ be the actuarial value (or the frictionless marginal cost) of policy $i$ in period $t$. The insurance company's profit in each period is

$$
\Pi_{t}=\sum_{i=1}^{I}\left(P_{i, t}-V_{i, t}\right) Q_{i, t}-C_{t} .
$$

A simple way to interpret this profit function is that for each type of policy that the insurance company sells for $P_{i, t}$, it can buy a portfolio of Treasury bonds that replicate its expected liabilities for $V_{i, t}$. For term annuities, this interpretation is exact because future insurance liabilities are deterministic. For life annuities and life insurance, we assume that the insured pools are sufficiently large for the law of large numbers to apply.

\footnotetext{
${ }^{6}$ We take the demand function as exogenously given because its microfoundations are not essential for our immediate purposes. In Appendix A, we derive the demand function from first principles in a fully specified model with search frictions.
} 
The insurance company chooses the price $P_{i, t}$ for each type of policy to maximize firm value, or the present value of profits:

$$
J_{t}=\Pi_{t}+\mathbb{E}_{t}\left[M_{t+1} J_{t+1}\right],
$$

where $M_{t+1}$ is the stochastic discount factor. The insurance company maximizes firm value, subject to the leverage constraint (13) and the law of motion for statutory capital (12).

\section{B. Optimal Insurance Pricing}

Let $\lambda_{t} \geq 0$ be the Lagrange multiplier on the leverage constraint (13)). The Lagrangian for the insurance company's maximization problem is

$$
L_{t}=J_{t}+\lambda_{t} K_{t}
$$

The first-order condition for the price of policy $i$ in period $t$ is

$$
\begin{aligned}
\frac{\partial L_{t}}{\partial P_{i, t}} & =\frac{\partial J_{t}}{\partial P_{i, t}}+\lambda_{t} \frac{\partial K_{t}}{\partial P_{i, t}}=\frac{\partial \Pi_{t}}{\partial P_{i, t}}+\bar{\lambda}_{t} \frac{\partial K_{t}}{\partial P_{i, t}} \\
& =Q_{i, t}+\left(P_{i, t}-V_{i, t}\right) \frac{\partial Q_{i, t}}{\partial P_{i, t}}+\bar{\lambda}_{t}\left[Q_{i, t}+\left(P_{i, t}-\phi^{-1} \widehat{V}_{i, t}\right) \frac{\partial Q_{i, t}}{\partial P_{i, t}}\right]=0,
\end{aligned}
$$

where we refer to

$$
\bar{\lambda}_{t}=-\frac{\partial \Pi_{t}}{\partial P_{i, t}}\left(\frac{\partial K_{t}}{\partial P_{i, t}}\right)^{-1}=\lambda_{t}+\mathbb{E}_{t}\left[M_{t+1} \frac{\partial J_{t+1}}{\partial K_{t}}\right]
$$

as the shadow cost of capital. It measures the marginal reduction in profits that the insurance company is willing to accept to raise its statutory capital by a dollar.

Rearranging equation (19), the price of policy $i$ in period $t$ is

$$
P_{i, t}=V_{i, t}\left(1-\frac{1}{\epsilon_{i, t}}\right)^{-1}\left(\frac{1+\bar{\lambda}_{t} \phi^{-1} \widehat{V}_{i, t} / V_{i, t}}{1+\bar{\lambda}_{t}}\right)
$$

where

$$
\epsilon_{i, t}=-\frac{\partial \log Q_{i, t}}{\partial \log P_{i, t}}>1
$$


is the elasticity of demand. When $\bar{\lambda}_{t}=0$, the insurance price reduces to

$$
\bar{P}_{i, t}=V_{i, t}\left(1-\frac{1}{\epsilon_{i, t}}\right)^{-1} .
$$

This is the standard Bertrand formula of pricing, in which price is equal to marginal cost times a markup that is decreasing in the elasticity of demand.

When $\bar{\lambda}_{t}>0$, the insurance price satisfies an inequality:

$$
P_{i, t} \gtrless \bar{P}_{i, t} \text { if } \frac{\widehat{V}_{i, t}}{V_{i, t}} \gtrless \phi \text {. }
$$

That is, the insurance price is higher than the Bertrand price if selling the policy reduces statutory capital on the margin. This is the case with property and casualty insurers, whose statutory reserve regulation requires that $\widehat{V}_{i, t} / V_{i, t}>1$ (Committee on Property and Liability Financial Reporting 2000). Conversely, the insurance price is lower than the Bertrand price if selling the policy raises statutory capital on the margin. This was the case with life insurers around December 2008, as shown in Figure 6.

The shadow cost of capital (20) embeds the importance of both financial and product market frictions. To see this, first consider a special case of the model in which product market frictions are absent (i.e., $\partial Q_{i, t} / \partial K_{t-1}=0$ ). The insurance company may reduce prices, sacrificing current economic profits, in order to relax current or future financial constraints. The incentive to reduce prices is increasing in the shadow cost, which measures the importance of statutory capital for relaxing the leverage constraint today (through $\lambda_{t}$ ) or at some future state (through $\mathbb{E}_{t}\left[M_{t+1} \partial J_{t+1} / \partial K_{t}\right]$ ).

Now consider a special case of the model in which financial frictions are absent (i.e., $\lambda_{t}=0$ in all periods). The insurance company may reduce prices, sacrificing current economic profits, in order to boost future demand. The incentive to engage in a price war is increasing in the shadow cost, which measures the importance of statutory capital for boosting future demand (through $\mathbb{E}_{t}\left[M_{t+1} \partial J_{t+1} / \partial K_{t}\right]$ ).

\section{Empirical Predictions}

The key predictions of the insurance pricing model (21) are consistent with the evidence in Section II. In the cross section of policies, the model predicts that the price reductions are larger for those policies with looser statutory reserve requirements (i.e., lower $\widehat{V}_{i, t} / V_{i, t}$ ). Consistent with this prediction, Figures 1 to 3 show that the price reductions during the financial crisis align with the differences in statutory reserve requirements across policies 
of different maturities in Figure 6. The model also explains why the extraordinary pricing behavior was so short-lived. Figure [6 shows that the reserve value was significantly lower than the actuarial value from November 2008 to February 2009, which was a relatively short window of opportunity for insurance companies to raise statutory capital through the sale of new policies.

In the cross section of insurance companies, the model predicts that the price reductions are larger for those companies with higher shadow cost of capital. Figure 4 supports this prediction if those companies that suffered larger balance sheet shocks had higher shadow cost, because they were either more constrained or more eager to boost future demand.

\section{Estimating the Insurance Pricing Model}

We now estimate the shadow cost of capital through the insurance pricing model (21). In Appendix A, we take a complementary approach of calibrating and solving a fully specified version of the model.

\section{A. Empirical Specification}

Let $i$ index the type of policy, $j$ index the insurance company, and $t$ index time. Equation (21) implies a nonlinear regression model for the markup:

$$
\log \left(\frac{P_{i, j, t}}{V_{i, t}}\right)=-\log \left(1-\frac{1}{\epsilon_{i, j, t}}\right)+\log \left(\frac{1+\bar{\lambda}_{j, t}\left(L_{j, t} / A_{j, t}\right)^{-1} \widehat{V}_{i, t} / V_{i, t}}{1+\bar{\lambda}_{j, t}}\right)+e_{i, j, t}
$$

where $e_{i, j, t}$ is an error term with zero conditional mean.

We model the elasticity of demand as

$$
\epsilon_{i, j, t}=1+\exp \left\{-\beta^{\prime} \mathbf{y}_{i, j, t}\right\}
$$

where $\mathbf{y}_{i, j, t}$ is a vector of insurance policy and company characteristics. The insurance policy characteristics in our specification are sex and age. The insurance company characteristics are the A.M. Best rating, log assets, asset growth, leverage ratio, risk-based capital relative to guideline, current liquidity, and operating return on equity. We interact each of these variables with a dummy variable that allows their impact on the elasticity of demand to differ between annuities and life insurance. We also include year-quarter and domiciliarystate dummies to capture additional variation in the elasticity of demand. 
We model the shadow cost of capital as

$$
\bar{\lambda}_{j, t}=\exp \left\{\gamma^{\prime} \mathbf{z}_{j, t}\right\}
$$

where $\mathbf{z}_{j, t}$ is a vector of insurance company characteristics. Motivated by the reduced-form evidence in Figure 4, the insurance company characteristics are log assets, asset growth, leverage ratio, risk-based capital relative to guideline, and net equity inflow. We capture time variation in the shadow cost through the yield spread between Moody's Aaa corporate and 20-year constant-maturity Treasury bonds. The corporate yield spread is an important measure of borrowing costs that is closely related to time-varying risk premia in financial markets, which could arise from time-varying risk aversion. Our specification also includes year-quarter dummies that allow the shadow cost to be zero, by essentially turning off both insurance company characteristics and the corporate yield spread.

\section{B. Identifying Assumptions}

If the elasticity of demand is correctly specified, equation (25) implies that the markup has a positive conditional mean whenever the shadow cost of capital is zero. Therefore, a positive shadow cost is identified by the combination of a negative conditional mean for the markup and a ratio of reserve to actuarial value that is less than the leverage ratio (i.e., $\left.\widehat{V}_{i, t} / V_{i, t}<L_{j, t} / A_{j, t}\right)$.

Even if the elasticity of demand is misspecified, Standard Valuation Law generates relative shifts in supply across different types of policies that an insurance company sells, which are sufficient to identify the shadow cost of capital. To illustrate this point, we approximate equation (25) through a first-order Taylor approximation as

$$
\log \left(\frac{P_{i, j, t}}{V_{i, t}}\right) \approx \alpha_{j, t}+\left(1+\frac{1}{\bar{\lambda}_{j, t}}\right)^{-1}\left(\frac{L_{j, t}}{A_{j, t}}\right)^{-1} \frac{\widehat{V}_{i, t}}{V_{i, t}}+u_{i, j, t}
$$

where

$$
u_{i, j, t}=-\alpha_{j, t}-\left(1+\frac{1}{\bar{\lambda}_{j, t}}\right)^{-1}-\log \left(1-\frac{1}{\epsilon_{i, j, t}}\right)+e_{i, j, t}
$$

is an error term with zero conditional mean. For a given insurance company $j$ at a given time $t$, the regression coefficient $\bar{\lambda}_{j, t}$ is identified by exogenous variation in reserve to actuarial value across different types of policies. 


\section{Shadow Cost of Capital}

Panel A of Table 3 reports the estimated coefficients in the model for the elasticity of demand (i.e., $\beta$ in equation (26) ). The positive coefficient on the dummy for A.M. Best rating implies that insurance companies rated $\mathrm{A}$ or $\mathrm{A}$ - face a lower elasticity of demand and have higher average markups than those rated $\mathrm{A}++$ or $\mathrm{A}+$. Similarly, the positive coefficients on log assets and the leverage ratio imply that larger and more leveraged insurance companies face a lower elasticity of demand and have higher average markups.

Panel B of Table 3 reports the estimated coefficients in the model for the shadow cost of capital (i.e., $\gamma$ in equation (27)). In the time series, the shadow cost is positively related to the corporate yield spread. A standard deviation increase in the corporate yield spread is associated with a 66 percent increase in the shadow cost. In the cross section of insurance companies, the shadow cost is positively related to the leverage ratio, risk-based capital relative to guideline, and net equity inflow, and is negatively related to log assets and asset growth. The most important of these characteristics is the leverage ratio, by an order of magnitude. A standard deviation increase in the leverage ratio is associated with a 155 percent increase in the shadow cost.

Figure 7 reports the time series of the shadow cost of capital for the average company (i.e., at the mean of the insurance company characteristics). The shadow cost is positive around the 2001 recession as well as during the financial crisis. Our point estimate of the shadow cost is $\$ 0.96$ per dollar of statutory capital in November 2008. That is, the average company was willing to accept a marginal reduction of $\$ 0.96$ in profits to raise its statutory capital by a dollar. The 95 percent confidence interval for the shadow cost ranges from $\$ 0.66$ to $\$ 1.39$ per dollar of statutory capital.

Table 4 reports the shadow cost of capital for the cross section of insurance companies in our sample in November 2008. The shadow cost varies significantly across insurance companies. At the top of the list is MetLife Investors USA Insurance Company, whose shadow cost was $\$ 5.53$ per dollar of statutory capital with a standard error of $\$ 1.52$. Its assets shrank by 9 percent in 2008, and its leverage ratio was 97 percent at fiscal year-end 2008. The relative weakness of MetLife's balance sheet is remarkable, given that it raised new capital in 2008 that was 163 percent of its equity at fiscal year-end 2007. The last column of the table shows that MetLife was not the only company that raised an extraordinary amount of capital, through capital injections from the holding company and reduction of stockholder dividends (Berry-Stölzle, Nini and Wende 2012, Niehaus 2013).

Near the bottom of Table 4 is American General Life Insurance Company with a shadow

cost of $\$ 0.13$ per dollar of statutory capital. Its assets grew by 6 percent in 2008, and its leverage ratio was 85 percent at fiscal year-end 2008. The relative strength of American 
General's balance sheet is due to new capital that it received from its holding company in 2008, as part of the government bailout of the American International Group.

\section{Evidence on Quantities}

The financial statements contain data on new policies issued at an aggregated level that is coarser than our pricing data. Specifically, they contain the total number of policies issued for immediate annuities and life insurance, which are not broken down by type of policy. With this caveat in mind, we now turn to the evidence on quantities.

If the price reductions are due to downward shifts in the supply curve, there should be a positive correlation between quantity changes and the shadow cost of capital in the cross section of insurance companies. Table 5 shows that there is such correlation in the data for the cross section of insurance companies in Table 4. A dollar increase in the shadow cost in November 2008 is associated with a 14.4 percentage point increase in the growth rate of quantities from 2007 to 2009.

\section{Discussion on Financial Frictions}

It is tempting to interpret Tables 3 and 4 as evidence for financial frictions. However, an insurance company that is part of a holding company can be financially constrained only if its parent is also constrained due to frictions in external capital markets, or its parent does not inject enough capital due to frictions in internal capital markets. We now discuss these two possibilities as part of a broader discussion on the merits and limitations of financial frictions as an explanation for the evidence.

\section{A. Frictions in External Capital Markets}

Table 6 lists all publicly held holding companies that are parents of the insurance subsidiaries in Table 4, For each holding company, the table describes significant activity to recapitalize from September 2008 to July 2009. We define significant activity as application for government assistance, issuance of public equity, or reduction or suspension of dividends.

At the top of Table [6 are seven companies that applied for the Troubled Asset Relief Program (TARP) and the ING Group, which received similar assistance from the Dutch government. Only the most constrained companies would ordinarily apply for government assistance because it comes with tighter capital regulation (e.g., forced suspension of dividends), restrictions on executive compensation, and potential loss of reputation in both product and capital markets. The six companies that applied for TARP could be subdivided into two categories. Allstate, the American International Group, and Prudential Financial 
were already bank holding companies that were eligible for TARP. Genworth Financial, Lincoln National, the Phoenix Companies, and Protective Life were originally insurance holding companies that had to acquire a bank in order to become eligible. Becoming a bank holding company means that they would be subject to Federal Reserve supervision, so these four companies were presumably constrained to take such a drastic step.

The second group in Table 6] consists of Manulife Financial and MetLife, which did not apply for government assistance but issued public equity during the financial crisis. For these companies as well as Protective Life and Prudential Financial, which ultimately issued public equity after withdrawing their application for TARP, we estimate the announcement effect of equity issuance on the stock price (e.g., Gron and Lucas 1998). The announcement effect has two potential interpretations. The first is that the announcement effect reflects the cost of external capital that arises from debt overhang. Equity issuance could signal that existing equity within the holding company, in addition to new capital that is raised, will be used to repay the existing debtholders, including the policyholders of the insurance subsidiaries. The second interpretation is that the announcement effect merely reflects private information about profitability, which would eventually be revealed to capital markets anyway (Myers and Majluf 1984). With this caveat in mind, the final column of Table 6 reports the announcement effect as an imperfect measure of the cost of external capital.7

To illustrate our calculation with an example, MetLife announced an equity issuance at the close of trading on October 7, 2008. Its market capitalization was $\$ 26,170$ million, and its abnormal return on the following day was -24.34 percent, according to the capital asset pricing model. Therefore, the announcement was associated with a $\$ 6,370=0.2434 \times$ $\$ 26,170$ million reduction in market capitalization. MetLife raised $\$ 2,286$ million in new capital, which implies an average cost of $\$ 2.79=\$ 6,370 / \$ 2,286$ per dollar of capital. This average cost of external capital for the holding company is the same order of magnitude as the marginal cost of internal capital for its insurance subsidiaries in Table 4. Any difference between the two may be justified by convexity in the cost of equity issuance and frictions in internal capital markets, as we discuss below.

The third group in Table 6 consists of five companies that did not issue public equity but reduced or suspended dividends during the financial crisis. These companies could have been financially constrained, but it is difficult to tell based on changes in dividend policy alone. The final group in the table consists of five companies for whom there was no significant activity to recapitalize. These companies were presumably unconstrained.

\footnotetext{
${ }^{7}$ It is difficult to estimate the announcement effect of applying for government assistance because the capital raised depends on the probability of success and the expected support conditional on success. Similarly, the capital raised from a dividend reduction depends on the expected duration of the reduction, which is difficult to estimate.
} 
On the one hand, some (if not many) of the holding companies in Table 6 appear constrained during the financial crisis, which supports the view that their insurance subsidiaries were also constrained. For these companies, the shadow cost of capital in Table 4 most likely reflects the cost of financial frictions. On the other hand, some of the holding companies in Table 6 appear relatively unconstrained. For these companies, the case for financial frictions is much less compelling, and the shadow cost of capital in Table 4 most likely reflects the incentives to engage in a price war due to product market frictions.

\section{B. Frictions in Internal Capital Markets}

The Insurance Holding Company System Regulatory Act (National Association of Insurance Commissioners 2011, Appendix A-440) restricts the movement of capital within a holding company as well as the payment of stockholder dividends to the parent. Through these laws, state regulators protect the interests of policyholders by preventing holding companies from extracting too much capital from their insurance subsidiaries. However, these laws could also lead to frictions in internal capital markets.

As discussed in A.M. Best Company (2011, p. 21), regulatory uncertainty over the ability to extract capital is an important source of risk for holding companies. Any capital that a holding company injects into its insurance subsidiary may not be paid back as dividends, at least in the foreseeable future. Moreover, this risk is greater in bad times when insurance companies are subject to more regulatory scrutiny. Importantly, regulatory uncertainty could alter the ex ante incentives of a holding company to inject capital into its insurance subsidiary. While difficult to prove or quantify, we raise frictions in internal capital markets as another possibility for why the capital injections may have been limited during the financial crisis.

\section{Evidence against Default Risk}

Pricing below actuarial value could reflect the possibility that policyholders may not receive the full face value of policies in the event of future default. Since policies are ultimately backed by the state guaranty fund (e.g., up to $\$ 250 \mathrm{~K}$ for annuities and $\$ 300 \mathrm{~K}$ for life insurance in California), the only scenario in which a policyholder would not be fully repaid is if all companies associated with the state guaranty fund were to systemically fail. During the financial crisis, the pricing of annuities and life insurance remained linear around the guaranteed amount, and pricing was uniform across states with different guaranty provisions. The absence of kinks in pricing around the guaranteed amount rules out idiosyncratic default risk that affects only some companies, but it does not rule out systematic default risk in which the state guaranty fund fails. 
Suppose we were to entertain an extreme scenario in which the state guaranty fund fails. Since life insurers are subject to risk-based capital regulation, risky assets (e.g., noninvestment-grade bonds, common and preferred stocks, nonperforming mortgages, and real estate) account for only 16 percent of their assets (Ellul, Jotikasthira and Lundblad 2011). The remainder of their assets are in safe asset classes such as cash, Treasury bonds, and investment-grade bonds. Under an extreme assumption that risky assets lose their value entirely, a reasonable lower bound on the recovery rate is 84 percent. To further justify this recovery rate, the asset deficiency in past cases of insolvency typically ranges from 5 to 10 percent and very rarely exceeds 15 percent (Gallanis 2009).

Let $d_{t}(l)$ be the risk-neutral default probability between year $l-1$ and $l$ at time $t$, and let $\theta$ be the recovery rate conditional on default. Then the market value of an $M$-year term annuity per dollar of income is

$$
V_{t}(M)=\sum_{m=1}^{M} \frac{\theta+(1-\theta) \prod_{l=1}^{m}\left(1-d_{t}(l)\right)}{R_{t}(m)^{m}} .
$$

Panel B of Table 7 reports the term structure of default probabilities implied by the markups on term annuities in panel A. For MetLife Investors USA Insurance Company, an annual default probability of 24.4 percent at the 1 - to 5 -year horizon and 17.9 percent at the 6 - to 10-year horizon justifies the markups on 5- and 10-year term annuities. There are no default probabilities that can justify the markups on term annuities with maturity greater than 15 years. This is because equation (30) implies that the markup cannot be less than 16 percent (i.e., one minus the recovery rate), which is clearly violated for term annuities with maturity greater than 25 years.

Panel $\mathrm{C}$ of Table 7 presents further evidence against default risk based on the term structure of risk-neutral default probabilities implied by credit default swaps on the holding company of the respective subsidiary in panel B. First, the 6- to 10-year default probability implied by term annuities is higher than that implied by credit default swaps for all companies, except American General Life Insurance Company. This finding is inconsistent with default risk given that the policyholders of an insurance subsidiary are senior to the creditors of its holding company. Second, term annuities imply an upward-sloping term structure of default probabilities, which does not match the downward-sloping term structure implied by credit default swaps. Finally, the relative ranking of default probabilities across the insurance subsidiaries in panel $\mathrm{B}$ does not align with the relative ranking across the respective holding companies in panel C.

In Appendix E, we also find out-of-sample evidence against default risk based on the absence of discounts on life annuities during the Great Depression, when the corporate 
default spread was even higher than the heights reached during the financial crisis. Only our explanation, based on financial and product market frictions interacting with statutory reserve regulation, is consistent with the evidence for both the Great Depression and the financial crisis.

\section{Conclusion}

We document extraordinary pricing behavior for annuities and life insurance during the financial crisis. The average markup was as low as -19 percent for annuities and -57 percent for life insurance. In the cross section of policies, the price reductions were larger for those policies with looser statutory reserve requirements. In the cross section of insurance companies, the price reductions were larger for those companies that suffered larger balance sheet shocks. Traditional demand-side hypotheses, such as adverse selection or default risk, do not explain our empirical findings.

Instead, the evidence supports the view that financial and regulatory frictions have a large and measurable impact on insurance markets. More broadly, our study highlights the importance of supply-side frictions in consumer financial markets. Previous work in household finance has mostly focused on demand-side frictions, such as borrowing constraints, asymmetric information, moral hazard, and bounded rationality. Although these frictions are undoubtedly important, we believe that supply-side frictions are also important for our understanding of market equilibrium and welfare.

Another broader implication of our study is that we provide micro evidence for a class of macro models based on financial frictions, which is a leading explanation for the Great Recession (see Gertler and Kiyotaki (2010) and Brunnermeier, Eisenbach and Sannikov (2013) for recent surveys). We believe that this literature would benefit from additional micro evidence on the cost of these frictions for other types of financial institutions, such as commercial banks and health insurance companies. Our empirical approach could be extended to estimate the shadow cost of capital for other types of financial institutions. 


\section{References}

A.M. Best Company, Best's Insurance Reports: Life/Health, United States and Canada, Oldwick, NJ: A.M. Best Company, 1993-2012.

_ _ Best's Statement File: Life/Health, United States, Oldwick, NJ: A.M. Best Company, 1999-2012.

_ _ "Understanding BCAR for Life and Health Insurers," A.M. Best Methodology, 2004.

_ , "MetLife Investors USA Insurance Company," in "Best's Insurance Reports: Life/Health, United States and Canada," Oldwick, NJ: A.M. Best Company, 2009.

_ _ "Best's Credit Rating Methodology: Global Life and Non-Life Insurance Edition," A.M. Best Methodology, 2011.

Anderson, Simon P., André de Palma, and Jacques-François Thisse, Discrete Choice Theory of Product Differentiation., Cambridge, MA: MIT Press, 1992.

Berry-Stölzle, Thomas R., Gregory P. Nini, and Sabine Wende, "External Financing in the Life Insurance Industry: Evidence from the Financial Crisis," 2012. Unpublished.

Brunnermeier, Markus K., Thomas M. Eisenbach, and Yuliy Sannikov, "Macroeconomics with Financial Frictions: A Survey," in Daron Acemoglu, Manuel Arellano, and Eddie Dekel, eds., Advances in Economics and Econometrics: Tenth World Congress, Vol. 2, Cambridge: Cambridge University Press, 2013, chapter 1, pp. 3-96.

Charupat, Narat, Mark J. Kamstra, and Moshe A. Milevsky, "The Annuity Duration Puzzle," 2012. Unpublished.

Committee on Property and Liability Financial Reporting, "P\&C Actuarial Issues Associated with Implementation of NAIC Accounting Practices and Procedures," 2000. American Academy of Actuaries.

Compulife Software, Compulife Historical Data, Harrodsburg, KY: Compulife Software, 2005-2011.

Ellul, Andrew, Chotibhak Jotikasthira, and Christian T. Lundblad, "Regulatory Pressure and Fire Sales in the Corporate Bond Market," Journal of Financial Economics, 2011, 101 (3), 596-620. 
$\ldots, \ldots$, , and Yihui Wang, "Is Historical Cost Accounting a Panacea? Market Stress, Incentive Distortions, and Gains Trading," 2012. Unpublished.

Froot, Kenneth A. and Paul G. J. O'Connell, "The Pricing of U.S. Catastrophe Reinsurance," in Kenneth A. Froot, ed., The Financing of Catastrophe Risk, Chicago: University of Chicago Press, 1999, chapter 5, pp. 195-232.

Gallanis, Peter G., "NOLHGA, the Life and Health Insurance Guaranty System, and the Financial Crisis of 2008-2009," 2009. National Organization of Life and Health Insurance Guaranty Associations.

Gertler, Mark and Nobuhiro Kiyotaki, "Financial Intermediation and Credit Policy in Business Cycle Analysis," in Benjamin M. Friedman and Michael Woodford, eds., Handbook of Monetary Economics, Vol. 3, Amsterdam: Elsevier, 2010, chapter 11, pp. 547-599.

Gron, Anne, "Property-Casualty Insurance Cycles, Capacity Constraints, and Empirical Results." PhD dissertation, MIT, Cambridge, MA 1990.

_ - "Evidence of Capacity Constraints in Insurance Markets," Journal of Law and Economics, 1994, 37 (2), 349-377.

and Deborah J. Lucas, "External Financing and Insurance Cycles," in David F. Bradford, ed., The Economics of Property-Casualty Insurance, Chicago: University of Chicago Press, 1998, chapter 1, pp. 5-28.

Gürkaynak, Refet S., Brian Sack, and Jonathan H. Wright, "The U.S. Treasury Yield Curve: 1961 to the Present," Journal of Monetary Economics, 2007, 54 (8), 2291-2304.

Hortaçsu, Ali and Chad Syverson, "Product Differentiation, Search Costs, and Competition in the Mutual Fund Industry: A Case Study of S\&P 500 Index Funds," Quarterly Journal of Economics, 2004, 119 (2), 403-456.

Lombardi, Louis J., Valuation of Life Insurance Liabilities, 4th ed., Winsted, CT: ACTEX Publications, 2006.

Merrill, Craig B., Taylor D. Nadauld, René M. Stulz, and Shane M. Sherlund, "Did Capital Requirements and Fair Value Accounting Spark Fire Sales in Distressed Mortgage-Backed Securities?," 2012. NBER Working Paper 18270. 
Mitchell, Olivia S., James M. Poterba, Mark J. Warshawsky, and Jeffrey R. Brown, "New Evidence on the Money's Worth of Individual Annuities," American Economic Review, 1999, 89 (5), 1299-1318.

Myers, Stewart C. and Nicholas S. Majluf, "Corporate Financing and Investment Decisions When Firms Have Information that Investors Do Not Have," Journal of Financial Economics, 1984, 13 (2), 187-221.

National Association of Insurance Commissioners, Accounting Practices and Procedures Manual, Kansas City, MO: National Association of Insurance Commissioners, 2011.

Niehaus, Gregory R., "Managing Capital and Insolvency Risk via Internal Capital Market Transactions: The Case of Life Insurers," 2013. Unpublished.

Rothschild, Michael and Joseph E. Stiglitz, "Equilibrium in Competitive Insurance Markets: An Essay on the Economics of Imperfect Information," Quarterly Journal of Economics, 1976, 90 (4), 630-649.

Shleifer, Andrei and Robert W. Vishny, "Liquidation Values and Debt Capacity: A Market Equilibrium Approach," Journal of Finance, 1992, 47 (4), 1343-1366.

Stern, Hersh L., Annuity Shopper, Englishtown, NJ: WebAnnuities Insurance Agency, 1989-2011.

— Comparative Annuity Reports, Englishtown, NJ: WebAnnuities Insurance Agency, 2007-2009.

Winter, Ralph A., "The Dynamics of Competitive Insurance Markets," Journal of Financial Intermediation, 1994, 3 (4), 379-415.

Yaari, Menahem E., "Uncertain Lifetime, Life Insurance, and the Theory of the Consumer," Review of Economic Studies, 1965, 32 (2), 137-150. 
Table 1: Sample of Life Insurers and Their Market Share

\begin{tabular}{|c|c|c|c|c|}
\hline \multirow[b]{3}{*}{ Year } & \multirow{2}{*}{\multicolumn{2}{|c|}{$\begin{array}{l}\text { Number of } \\
\text { insurance } \\
\text { companies }\end{array}$}} & \multicolumn{2}{|c|}{$\begin{array}{c}\text { Percent of } \\
\text { market covered }\end{array}$} \\
\hline & & & \multirow{2}{*}{$\begin{array}{r}\text { Immediate } \\
\text { annuities }\end{array}$} & \multirow{2}{*}{$\begin{array}{r}\text { Life } \\
\text { insurance }\end{array}$} \\
\hline & Total & Covered & & \\
\hline 1998 & 399 & 25 & 17 & \\
\hline 1999 & 369 & 19 & 9 & \\
\hline 2000 & 378 & 19 & 7 & \\
\hline 2001 & 369 & 17 & 14 & \\
\hline 2002 & 337 & 10 & 11 & \\
\hline 2003 & 326 & 12 & 23 & \\
\hline 2004 & 316 & 13 & 17 & \\
\hline 2005 & 317 & 38 & 30 & 36 \\
\hline 2006 & 299 & 38 & 28 & 38 \\
\hline 2007 & 294 & 44 & 32 & 39 \\
\hline 2008 & 285 & 45 & 29 & 42 \\
\hline 2009 & 273 & 37 & 48 & 41 \\
\hline 2010 & 281 & 42 & 52 & 37 \\
\hline 2011 & 275 & 47 & 61 & 42 \\
\hline All & 489 & 101 & & \\
\hline
\end{tabular}

This table reports the total number of life insurers with an A.M. Best rating of A- or higher and agencyor broker-based marketing. It also reports the subset of these companies for which we have annuity or life insurance prices and their market share by total face amount of immediate annuities and life insurance issued. 
Table 2: Summary Statistics for Annuity and Life Insurance Prices

\begin{tabular}{llllllr}
\hline & & & & \multicolumn{3}{c}{ Markup (percent) } \\
\cline { 5 - 7 } Type of policy & Sample begins & Frequency & Observations & Mean & Median & $\begin{array}{r}\text { Standard } \\
\text { deviation }\end{array}$ \\
\hline Term annuities: & & & & & & \\
5 years & December 1992 & Semiannual & 646 & 6.5 & 6.7 & 3.7 \\
10 years & January 1989 & Semiannual & 870 & 7.0 & 7.2 & 4.2 \\
15 years & May 1998 & Semiannual & 394 & 4.4 & 4.5 & 4.7 \\
20 years & May 1998 & Semiannual & 390 & 4.1 & 4.0 & 5.7 \\
25 years & May 1998 & Semiannual & 318 & 3.7 & 3.7 & 6.7 \\
30 years & May 1998 & Semiannual & 309 & 3.1 & 3.2 & 7.9 \\
Life annuities: & & & & & & \\
Life only & January 1989 & Monthly & 13,675 & 7.9 & 8.4 & 7.6 \\
10-year guarantee & May 1998 & Monthly & 10,221 & 4.2 & 4.9 & 6.7 \\
20-year guarantee & May 1998 & Semiannual & 6,248 & 4.5 & 4.9 & 6.5 \\
Universal life insurance & January 2005 & Monthly & 31,226 & -5.8 & -6.5 & 16.0 \\
\hline
\end{tabular}

The markup is defined as the percent deviation of the quoted price from actuarial value. The actuarial value is based on the appropriate basic mortality table from the American Society of Actuaries and the zero-coupon Treasury yield curve. The sample covers life insurers with an A.M. Best rating of A- or higher from January 1989 to July 2011. 
Table 3: Estimated Model of Insurance Pricing

\begin{tabular}{lrc}
\hline Explanatory variable & \multicolumn{2}{c}{ Coefficient } \\
\hline Panel A. Elasticity of demand & & \\
A.M. Best rating of A or A- & 0.102 & $(0.021)$ \\
Log assets & 0.197 & $(0.014)$ \\
Asset growth & 0.011 & $(0.006)$ \\
Leverage ratio & 0.168 & $(0.019)$ \\
Risk-based capital relative to guideline & -0.022 & $(0.010)$ \\
Current liquidity & 0.067 & $(0.014)$ \\
Operating return on equity & 0.082 & $(0.011)$ \\
Female & 0.003 & $(0.003)$ \\
Age 50 & 0.060 & $(0.050)$ \\
Age 55 & 0.116 & $(0.046)$ \\
Age 60 & 0.170 & $(0.040)$ \\
Age 65 & 0.247 & $(0.039)$ \\
Age 70 & 0.353 & $(0.039)$ \\
Age 75 & 0.435 & $(0.040)$ \\
Age 80 & 0.438 & $(0.046)$ \\
Age 85 & 0.559 & $(0.054)$ \\
Interaction effects for life insurance & & \\
A.M. Best rating of A or A- & -2.896 & $(0.482)$ \\
Log assets & -3.600 & $(0.472)$ \\
Asset growth & -1.172 & $(0.192)$ \\
Leverage ratio & -0.216 & $(0.053)$ \\
Risk-based capital relative to guideline & -0.118 & $(0.040)$ \\
Current liquidity & -0.232 & $(0.102)$ \\
Operating return on equity & -0.862 & $(0.141)$ \\
Female & -0.074 & $(0.045)$ \\
Age 30 & -6.522 & $(1.257)$ \\
Age 40 & -6.997 & $(1.274)$ \\
Age 50 & -6.930 & $(1.259)$ \\
Age 60 & -6.801 & $(1.258)$ \\
Age 70 & -6.439 & $(1.248)$ \\
Age 80 & -6.419 & $(1.247)$ \\
Panel B. Shadow cost of capital & & \\
Corporate yield spread & 0.660 & $(0.052)$ \\
Log assets & -0.240 & $(0.034)$ \\
Asset growth & -0.255 & $(0.030)$ \\
Leverage ratio & 1.545 & $(0.130)$ \\
Risk-based capital relative to guideline & 0.393 & $(0.047)$ \\
Net equity inflow & 0.085 & $(0.024)$ \\
$R^{2}$ & 0.232 & \\
Observations & & \\
\hline & & \\
& & \\
& &
\end{tabular}

This table reports the coefficients in the models for the elasticity of demand (26) and the shadow cost of capital (27). The omitted categories for the dummy variables are term annuities, A.M. Best rating of A++ or A+, and male. The model for the elasticity of demand also includes year-quarter and domiciliary-state dummies, which are not reported for brevity. The model for the shadow cost also includes year-quarter dummies, which are not reported for brevity. Robust standard errors, reported in parentheses, are clustered by insurance company, type of policy, sex, and age. The sample covers life insurers with an A.M. Best rating of A- or higher from May 1998 to July 2011. 
Table 4: Shadow Cost of Capital in November 2008

\begin{tabular}{|c|c|c|c|c|c|c|}
\hline \multirow{2}{*}{$\begin{array}{l}\text { Insurance company } \\
\text { MetLife Investors USA Insurance }\end{array}$} & \multirow{2}{*}{$\begin{array}{l}\text { Holding company } \\
\text { MetLife }\end{array}$} & \multicolumn{2}{|c|}{$\begin{array}{r}\text { Shadow cost } \\
\text { (dollars) }\end{array}$} & \multirow{2}{*}{$\begin{array}{r}\begin{array}{r}\text { Asset } \\
\text { growth } \\
\text { (percent) }\end{array} \\
-9\end{array}$} & \multirow{2}{*}{$\begin{array}{r}\begin{array}{r}\text { Leverage } \\
\text { ratio } \\
\text { (percent) }\end{array} \\
97\end{array}$} & \multirow{2}{*}{$\begin{array}{r}\text { Net equity } \\
\text { inflow } \\
\text { (percent) }\end{array}$} \\
\hline & & 5.53 & $(1.52)$ & & & \\
\hline Pruco Life Insurance & Prudential Financial & 5.38 & $(1.39)$ & -19 & 97 & 43 \\
\hline National Integrity Life Insurance & & 5.37 & $(1.20)$ & 10 & 95 & 59 \\
\hline John Hancock Life Insurance of New York & Manulife Financial & 5.02 & $(1.39)$ & -15 & 96 & 134 \\
\hline Pruco Life Insurance of New Jersey & Prudential Financial & 4.97 & $(1.26)$ & -13 & 97 & 0 \\
\hline AXA Equitable Life Insurance & AXA & 4.52 & $(1.12)$ & -22 & 97 & 0 \\
\hline John Hancock Life Insurance (USA) & Manulife Financial & 3.87 & $(1.09)$ & -18 & 98 & 25 \\
\hline Lincoln National Life Insurance & Lincoln National & 3.50 & $(0.82)$ & -17 & 96 & -7 \\
\hline Sun Life Assurance of Canada (US) & Sun Life Financial & 3.31 & $(0.88)$ & -11 & 97 & 95 \\
\hline Phoenix Life Insurance & Phoenix Companies & 3.06 & $(0.64)$ & -8 & 94 & -7 \\
\hline OM Financial Life Insurance & Old Mutual & 2.88 & $(0.66)$ & -4 & 95 & 44 \\
\hline Aviva Life and Annuity of New York & Aviva & 2.75 & $(0.61)$ & 4 & 94 & 25 \\
\hline Allianz Life Insurance of North America & Allianz Group & 2.75 & $(0.70)$ & -3 & 97 & 22 \\
\hline Texas Life Insurance & & 2.44 & $(0.51)$ & 5 & 93 & 0 \\
\hline United States Life Insurance in City of New York & American International Group & 2.19 & $(0.51)$ & 0 & 94 & 90 \\
\hline EquiTrust Life Insurance & FBL Financial Group & 2.18 & $(0.47)$ & 14 & 95 & 20 \\
\hline Integrity Life Insurance & & 2.07 & $(0.40)$ & 3 & 92 & 25 \\
\hline OM Financial Life Insurance of New York & Old Mutual & 1.96 & $(0.42)$ & -2 & 93 & 0 \\
\hline Companion Life Insurance & & 1.92 & $(0.39)$ & 4 & 91 & 0 \\
\hline Sun Life Insurance and Annuity of New York & Sun Life Financial & 1.85 & $(0.37)$ & -2 & 92 & 69 \\
\hline Genworth Life Insurance of New York & Genworth Financial & 1.80 & $(0.38)$ & 8 & 94 & 40 \\
\hline Aviva Life and Annuity & Aviva & 1.65 & $(0.36)$ & 12 & 95 & 7 \\
\hline Protective Life and Annuity Insurance & Protective Life & 1.50 & $(0.35)$ & 21 & 94 & 0 \\
\hline North American for Life and Health Insurance & & 1.49 & $(0.30)$ & 27 & 93 & 30 \\
\hline Cincinnati Life Insurance & Cincinnati Financial & 1.36 & $(0.30)$ & -3 & 88 & 0 \\
\hline Genworth Life and Annuity Insurance & Genworth Financial & 1.28 & $(0.25)$ & -11 & 92 & 39 \\
\hline Security Life of Denver Insurance & ING Group & 1.26 & $(0.28)$ & 0 & 94 & 14 \\
\hline ReliaStar Life Insurance of New York & ING Group & 1.21 & $(0.26)$ & -1 & 92 & 29 \\
\hline C.M. Life Insurance & & 1.13 & $(0.21)$ & -13 & 90 & 0 \\
\hline Metropolitan Life Insurance & MetLife & 1.08 & $(0.25)$ & -3 & 94 & -8 \\
\hline Kansas City Life Insurance & Kansas City Life Insurance & 1.07 & $(0.21)$ & -8 & 89 & -2 \\
\hline United of Omaha Life Insurance & & 1.06 & $(0.20)$ & -3 & 90 & -8 \\
\hline William Penn Life Insurance of New York & Legal and General Group & 1.03 & $(0.20)$ & -1 & 90 & 0 \\
\hline Lincoln Life and Annuity of New York & Lincoln National & 0.94 & $(0.18)$ & -6 & 90 & 0 \\
\hline Ohio National Life Assurance Corporation & & 0.93 & $(0.18)$ & 2 & 90 & 0 \\
\hline Protective Life Insurance & Protective Life & 0.87 & $(0.18)$ & 0 & 92 & 5 \\
\hline Penn Mutual Life Insurance & & 0.68 & $(0.17)$ & -8 & 86 & 0 \\
\hline Lincoln Benefit Life & Allstate & 0.59 & $(0.13)$ & -37 & 87 & 0 \\
\hline Illinois Mutual Life Insurance & & 0.58 & $(0.12)$ & 1 & 89 & 0 \\
\hline West Coast Life Insurance & Protective Life & 0.57 & $(0.12)$ & 9 & 90 & 47 \\
\hline Genworth Life Insurance & Genworth Financial & 0.50 & $(0.10)$ & 0 & 90 & 9 \\
\hline Banner Life Insurance & Legal and General Group & 0.19 & $(0.05)$ & 3 & 84 & 42 \\
\hline American National Insurance & American National Insurance & 0.18 & $(0.04)$ & -2 & 86 & -3 \\
\hline American General Life Insurance & American International Group & 0.13 & $(0.03)$ & 6 & 85 & 142 \\
\hline AAA Life Insurance & & 0.10 & $(0.03)$ & 25 & 81 & 14 \\
\hline
\end{tabular}

This table reports the shadow cost of capital for the life insurers in our sample in November 2008, implied by the estimated model of insurance pricing. Robust standard errors, reported in parentheses, are based on the delta method. Asset growth is from fiscal year-end 2007 to 2008 . The leverage ratio and net equity inflow are at fiscal year-end 2008. 
Table 5: Relation between Quantity Changes and the Shadow Cost of Capital

\begin{tabular}{lr}
\hline Explanatory variable & Coefficient \\
\hline Shadow cost & 14.4 \\
& $(4.1)$ \\
$R^{2}$ & 0.25 \\
Observations & 45 \\
\hline
\end{tabular}

The percent change in quantities, averaged over immediate annuities and life insurance issued, is from 2007 to 2009. The shadow cost of capital in November 2008 is for the cross section of insurance companies in Table 4. The linear regression weights the observations by total admitted assets at fiscal year-end 2007. Heteroskedasticity-robust standard errors are reported in parentheses. 
Table 6: Significant Activity to Recapitalize by the Holding Companies

\begin{tabular}{|c|c|c|c|}
\hline Holding company & Date & Significant activity & $\begin{array}{r}\text { Announcement } \\
\text { effect } \\
\text { (dollars) }\end{array}$ \\
\hline \multicolumn{4}{|c|}{ Panel A. Applied for government assistance } \\
\hline \multirow[t]{4}{*}{ Allstate } & $11 / 14 / 2008$ & Applies for TARP. & \\
\hline & $2 / 25 / 2009$ & Reduces quarterly dividend from $\$ 0.41$ to $\$ 0.20$ per share. & \\
\hline & $5 / 15 / 2009$ & Receives approval for TARP. & \\
\hline & $5 / 19 / 2009$ & Withdraws application for TARP. & \\
\hline \multirow[t]{2}{*}{ American International Group } & $9 / 22 / 2008$ & Suspends dividends under an $\$ 85$ billion credit agreement with the New York Fed. & \\
\hline & $11 / 25 / 2008$ & Issues $\$ 40$ billion of preferred equity to the US Treasury under TARP. & \\
\hline \multirow[t]{3}{*}{ Genworth Financial } & $11 / 1 / 2008$ & Suspends dividends. & \\
\hline & $11 / 16 / 2008$ & Applies for TARP with plans to acquire InterBank, FSB. & \\
\hline & $4 / 9 / 2009$ & Is rejected for TARP and cancels the acquisition of InterBank, FSB. & \\
\hline \multirow{2}{*}{ ING Group } & $10 / 19 / 2008$ & Issues 10 billion euros of preferred equity to the Dutch government. & \\
\hline & $10 / 19 / 2008$ & Suspends dividends. & \\
\hline \multirow[t]{5}{*}{ Lincoln National } & $10 / 10 / 2008$ & Reduces quarterly dividend from $\$ 0.415$ to $\$ 0.21$ per share. & \\
\hline & $11 / 13 / 2008$ & Applies for TARP with plans to acquire Newton County Loan and Savings, FSB. & \\
\hline & $2 / 24 / 2009$ & Reduces quarterly dividend from $\$ 0.21$ to $\$ 0.01$ per share. & \\
\hline & $6 / 22 / 2009$ & Issues $\$ 690$ million of common equity. & \\
\hline & $7 / 10 / 2009$ & Issues $\$ 950$ million of preferred equity to the US Treasury under TARP. & \\
\hline \multirow[t]{3}{*}{ Phoenix Companies } & $1 / 15 / 2009$ & Applies for TARP with plans to acquire American Sterling Bank. & \\
\hline & $2 / 7 / 2009$ & Suspends dividends. & \\
\hline & $4 / 20 / 2009$ & Withdraws application for TARP after failing to acquire American Sterling Bank. & \\
\hline \multirow[t]{4}{*}{ Protective Life } & $11 / 3 / 2008$ & Reduces quarterly dividend from $\$ 0.235$ to $\$ 0.12$ per share. & \\
\hline & $1 / 15 / 2009$ & Applies for TARP with plans to acquire Bonifay Holding Company. & \\
\hline & $4 / 1 / 2009$ & Withdraws application for TARP after failing to acquire Bonifay Holding Company. & \\
\hline & $5 / 20 / 2009$ & Issues $\$ 133$ million of common equity. & 0.76 \\
\hline \multirow[t]{5}{*}{ Prudential Financial } & $10 / 1 / 2008$ & Applies for TARP. & \\
\hline & $11 / 11 / 2008$ & Reduces annual dividend from $\$ 1.15$ to $\$ 0.58$ per share. & \\
\hline & $5 / 14 / 2009$ & Receives approval for TARP. & \\
\hline & $6 / 1 / 2009$ & Withdraws application for TARP. & \\
\hline & $6 / 9 / 2009$ & Issues $\$ 1,438$ million of common equity. & 1.18 \\
\hline \multicolumn{4}{|l|}{ Panel B. Issued public equity } \\
\hline \multirow[t]{4}{*}{ Manulife Financial } & $12 / 11 / 2008$ & Issues $\$ 2,275$ million of common equity. & 0.72 \\
\hline & $3 / 4 / 2009$ & Issues $\$ 450$ million of preferred equity. & \\
\hline & $6 / 3 / 2009$ & Issues $\$ 350$ million of preferred equity. & \\
\hline & $8 / 6 / 2009$ & Reduces quarterly dividend from $\$ 0.26$ to $\$ 0.13$ per share. & \\
\hline MetLife & $10 / 15 / 2008$ & Issues $\$ 2,286$ million of common equity. & 2.79 \\
\hline \multicolumn{4}{|c|}{ Panel C. Reduced or suspended dividends } \\
\hline Allianz Group & $2 / 26 / 2009$ & Reduces annual dividend from 5.50 to 3.50 euros per share. & \\
\hline AXA & $4 / 30 / 2009$ & Reduces annual dividend from 1.20 to 0.40 euros per share. & \\
\hline FBL Financial Group & $5 / 21 / 2009$ & Reduces quarterly dividend from $\$ 0.125$ to $\$ 0.0625$ per share. & \\
\hline Legal and General Group & $3 / 25 / 2009$ & Reduces final dividend from 4.10 to 2.05 pence per share. & \\
\hline Old Mutual & $3 / 4 / 2009$ & Suspends dividends. & \\
\hline \multicolumn{4}{|c|}{ Panel D. No significant activity } \\
\hline \multicolumn{4}{|l|}{ American National Insurance } \\
\hline \multicolumn{4}{|l|}{ Aviva } \\
\hline \multicolumn{4}{|l|}{ Cincinnati Financial } \\
\hline \multicolumn{4}{|l|}{ Kansas City Life Insurance } \\
\hline Sun Life Financial & & & \\
\hline
\end{tabular}

This table reports significant activity to recapitalize by the holding companies from September 2008 to July 2009. The holding companies are grouped into those that applied for government assistance through the Troubled Asset Relief Program (TARP) or similar foreign programs, those that issued public equity, those that reduced or suspended dividends, and those with no significant activity. 
Table 7: Default Probabilities Implied by Term Annuities versus Credit Default Swaps in November 2008

\begin{tabular}{lrrrrrr}
\hline & \multicolumn{7}{c}{ Maturity (years) } \\
\cline { 2 - 7 } Company & 5 & 10 & 15 & 20 & 25 & 30 \\
\hline Panel A. Markup (percent) & \multicolumn{7}{c}{. } & & & & \\
Allianz Life Insurance of North America & 0.4 & -2.9 & -7.7 & -12.8 & -18.2 & -21.7 \\
Lincoln Benefit Life & -1.4 & -4.6 & -6.3 & -7.8 & -9.9 & -12.6 \\
MetLife Investors USA Insurance & & -9.2 & -12.1 & -14.5 & -17.3 & -20.9 \\
Genworth Life Insurance & 0.0 & -2.6 & -4.0 & -5.9 & -8.7 & -12.4 \\
Aviva Life and Annuity & 0.1 & -1.5 & -2.1 & -4.3 & -7.9 & -11.9 \\
American General Life Insurance & -2.4 & -3.3 & -4.6 & -7.8 & -10.6 & -14.2 \\
Panel B. Default probabilities implied by term & annuities & (percent) & & \\
Allianz Life Insurance of North America & 0.0 & 72.6 & 100.0 & 100.0 & 100.0 & 100.0 \\
Lincoln Benefit Life & 3.2 & 19.6 & 16.5 & 100.0 & 100.0 & 100.0 \\
MetLife Investors USA Insurance & 24.4 & 17.9 & 100.0 & 100.0 & 100.0 & 100.0 \\
Genworth Life Insurance & 0.1 & 15.4 & 14.5 & 100.0 & 100.0 & 100.0 \\
Aviva Life and Annuity & 0.0 & 8.4 & 10.1 & 100.0 & 100.0 & 100.0 \\
American General Life Insurance & 5.4 & 1.6 & 78.6 & 100.0 & 100.0 & 100.0 \\
Panel C. Default probabilities implied by credit & default swaps (percent) & \\
Allianz Group & 1.9 & 1.8 & & & & \\
Allstate & 4.6 & 3.7 & & & & \\
MetLife & 10.0 & 6.0 & & & & \\
Genworth Financial & 32.8 & 4.8 & & & & \\
Aviva & 2.8 & 2.7 & & & & \\
American International Group & 20.3 & 5.8 &
\end{tabular}

Panel B reports the term structure of annual risk-neutral default probabilities that justify the markups on term annuities in panel A. An implied default probability of 100 percent means that the markups are too low to be justified by default risk, given a recovery rate of 84 percent. Panel $\mathrm{C}$ reports the term structure of annual risk-neutral default probabilities implied by 5- and 10-year credit default swaps on the holding company of the respective subsidiary in panel B. Appendix D describes how we estimate the term structure of risk-neutral default probabilities from credit default swaps. 
30-year term annuities

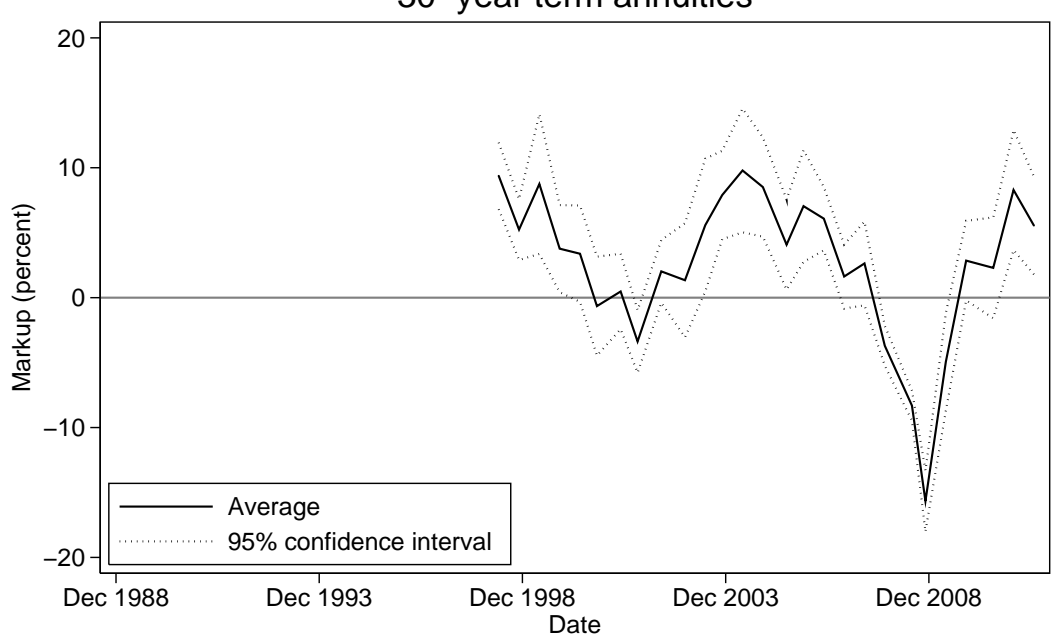

10-year term annuities

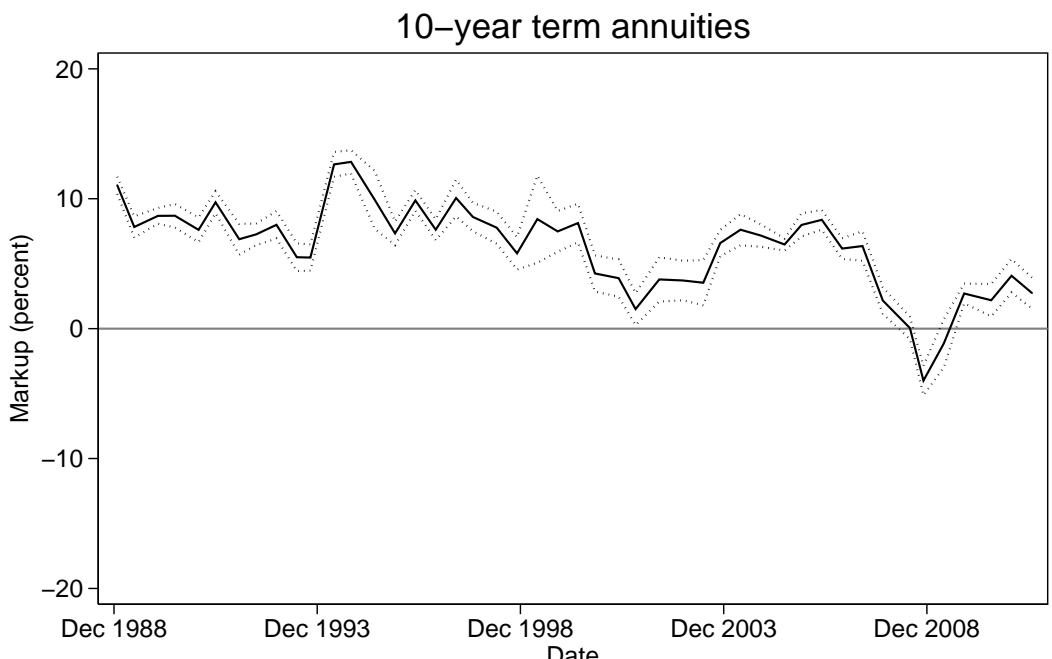

20-year term annuities

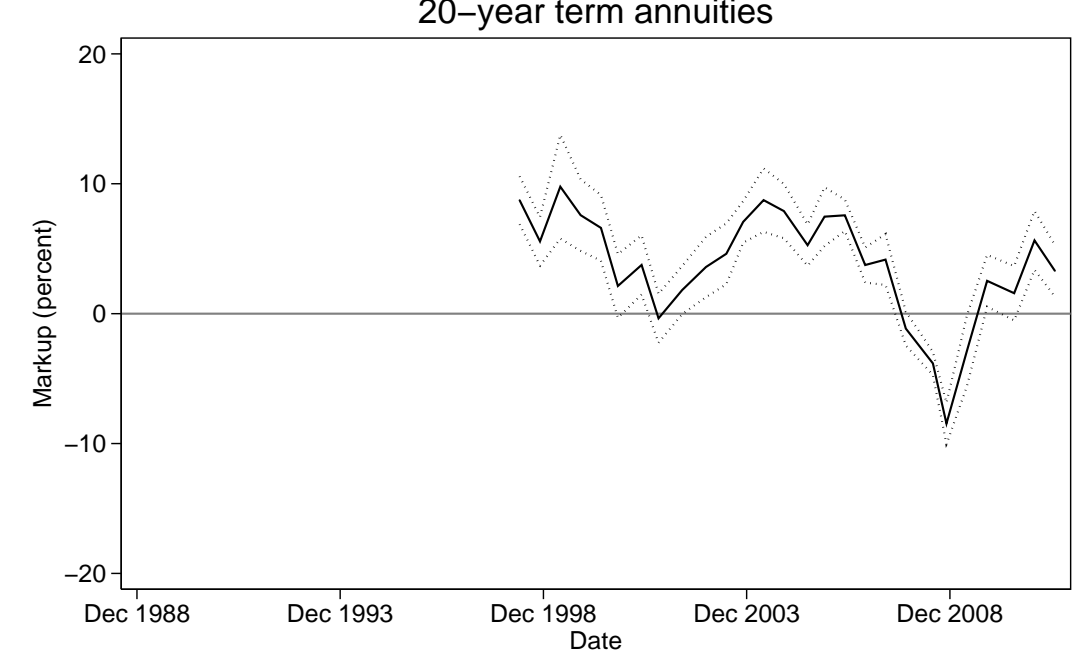

5-year term annuities

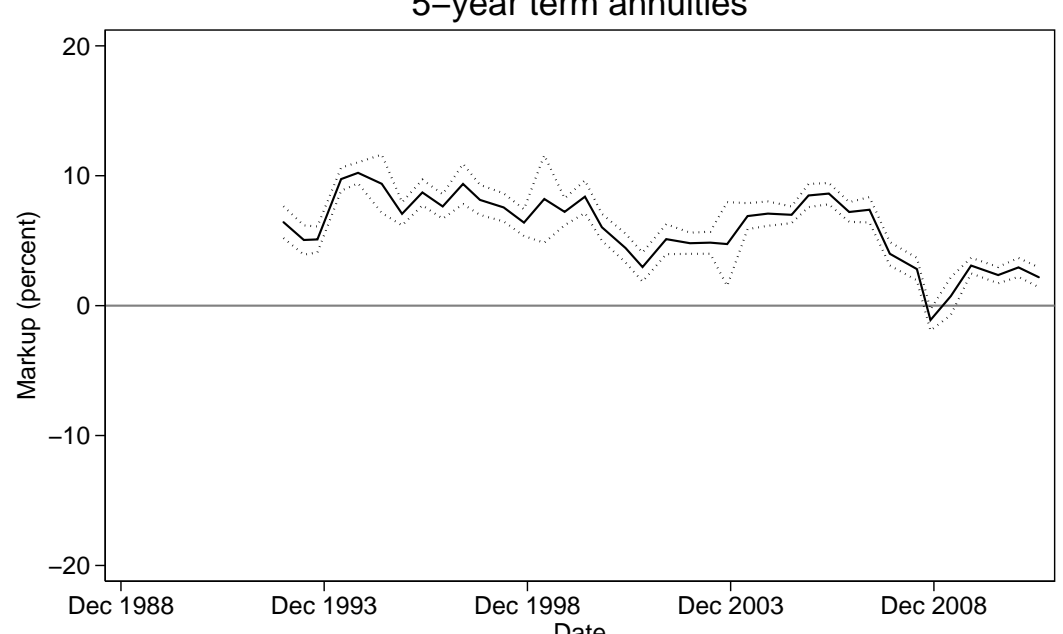

Figure 1: Average Markup on Term Annuities

The markup is defined as the percent deviation of the quoted price from actuarial value. The actuarial value is based on the zero-coupon Treasury yield curve. The sample covers life insurers with an A.M. Best rating of A- or higher from January 1989 to July 2011. 

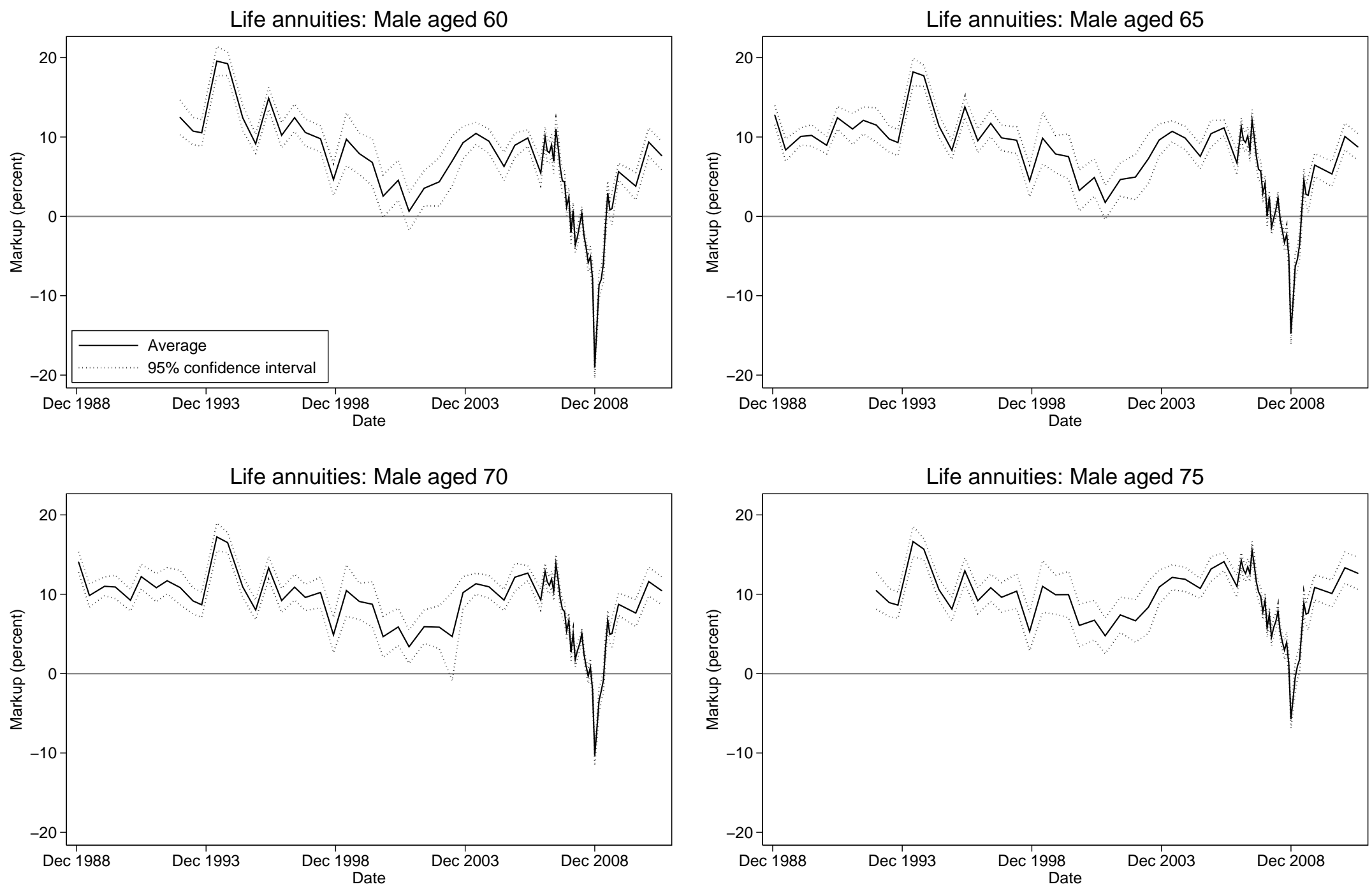

Figure 2: Average Markup on Life Annuities

The markup is defined as the percent deviation of the quoted price from actuarial value. The actuarial value is based on the appropriate basic mortality table from the American Society of Actuaries and the zero-coupon Treasury yield curve. The sample covers life insurers with an A.M. Best rating of A- or higher from January 1989 to July 2011. 

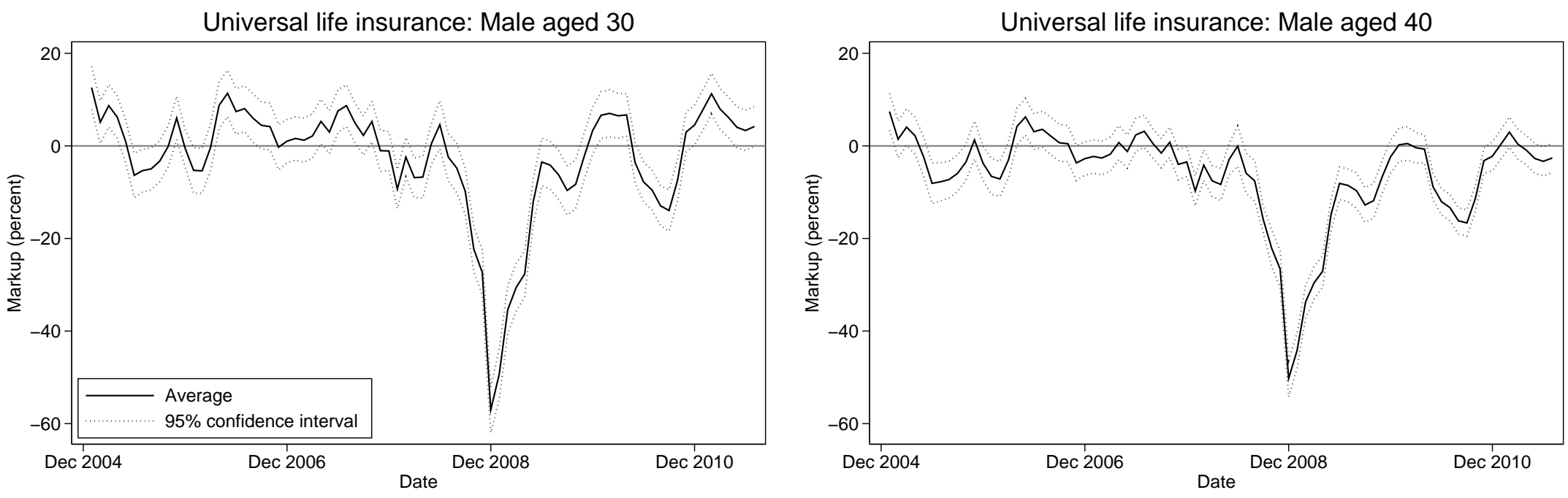

$\infty$
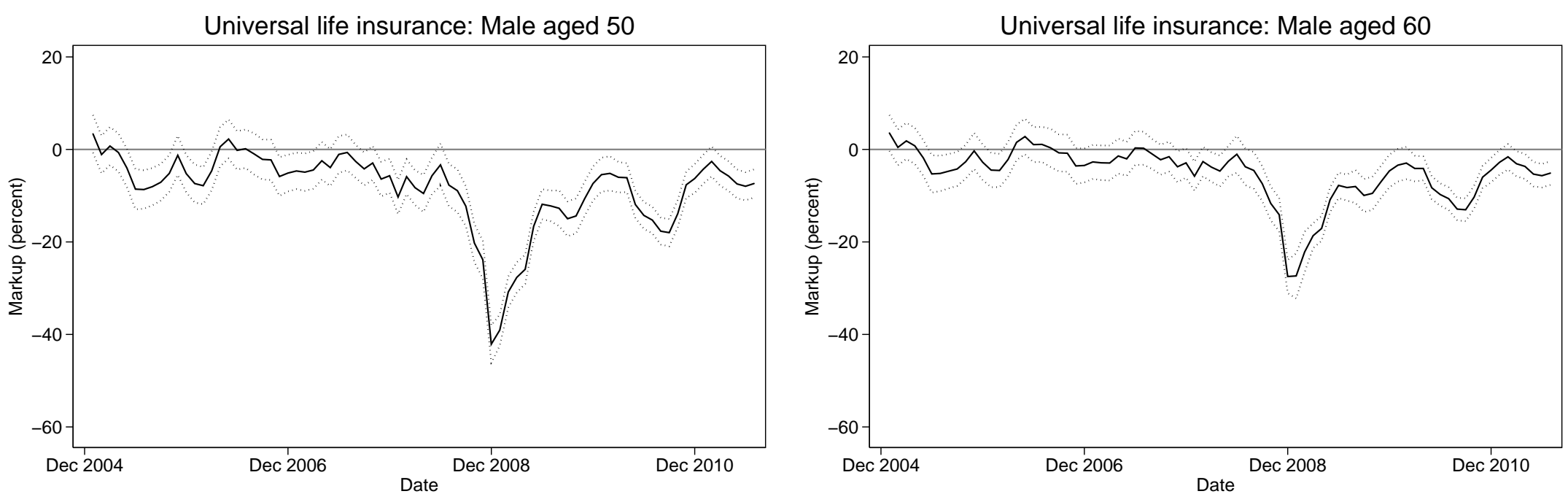

Figure 3: Average Markup on Life Insurance

The markup is defined as the percent deviation of the quoted price from actuarial value. The actuarial value is based on the appropriate basic mortality table from the American Society of Actuaries and the zero-coupon Treasury yield curve. The monthly sample covers life insurers with an A.M. Best rating of A- or higher from January 2005 to July 2011. 

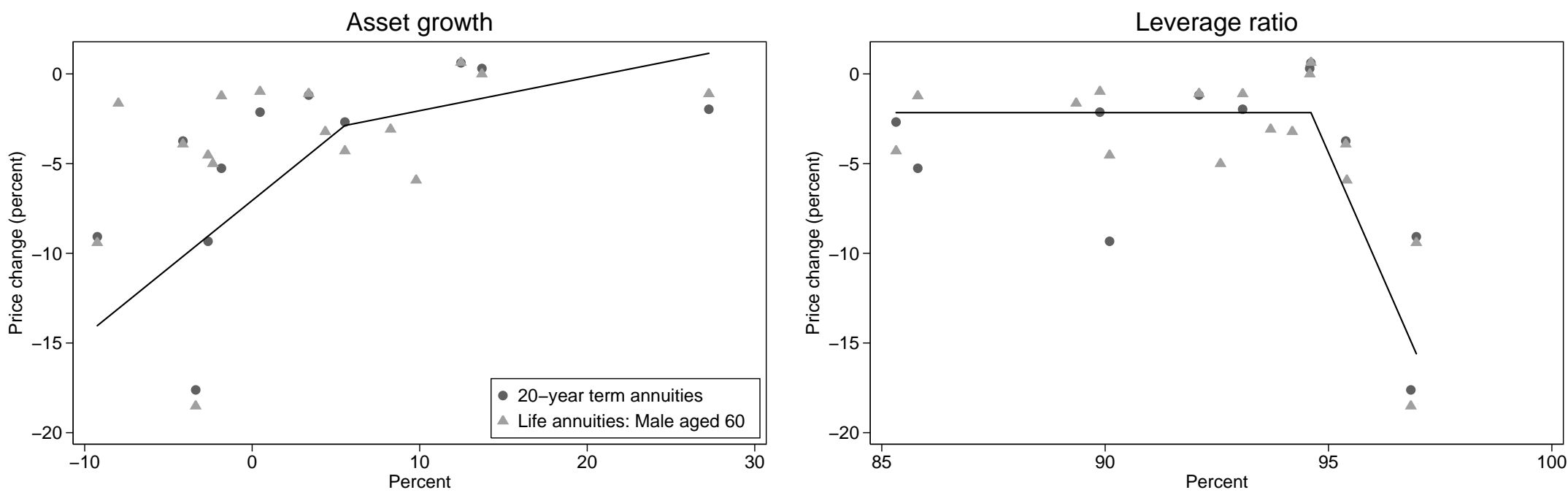

Risk-based capital relative to guideline
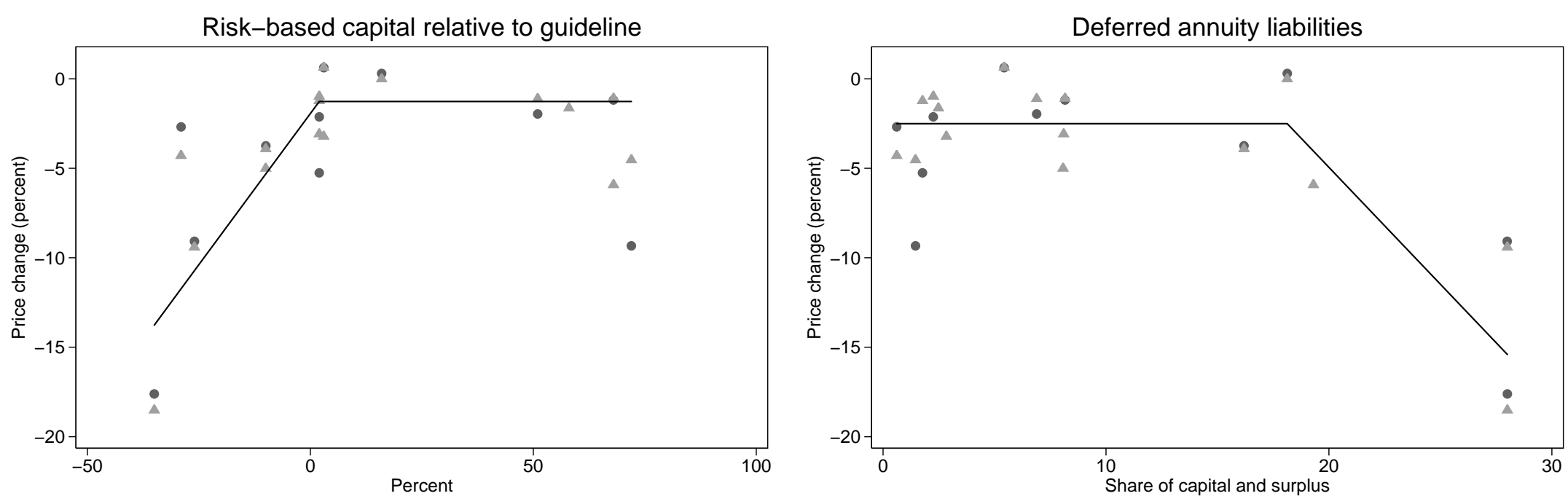

Figure 4: Relation between Price Changes and Balance Sheet Shocks

The percent change in annuity prices is from May 2007 to November 2008. Asset growth is from fiscal year-end 2007 to 2008 . The leverage ratio, risk-based capital relative to guideline, and the ratio of deferred annuity liabilities to equity are at fiscal year-end 2008. The best-fitting monotone linear spline with one knot weights the observations by total admitted assets at fiscal year-end 2007. 


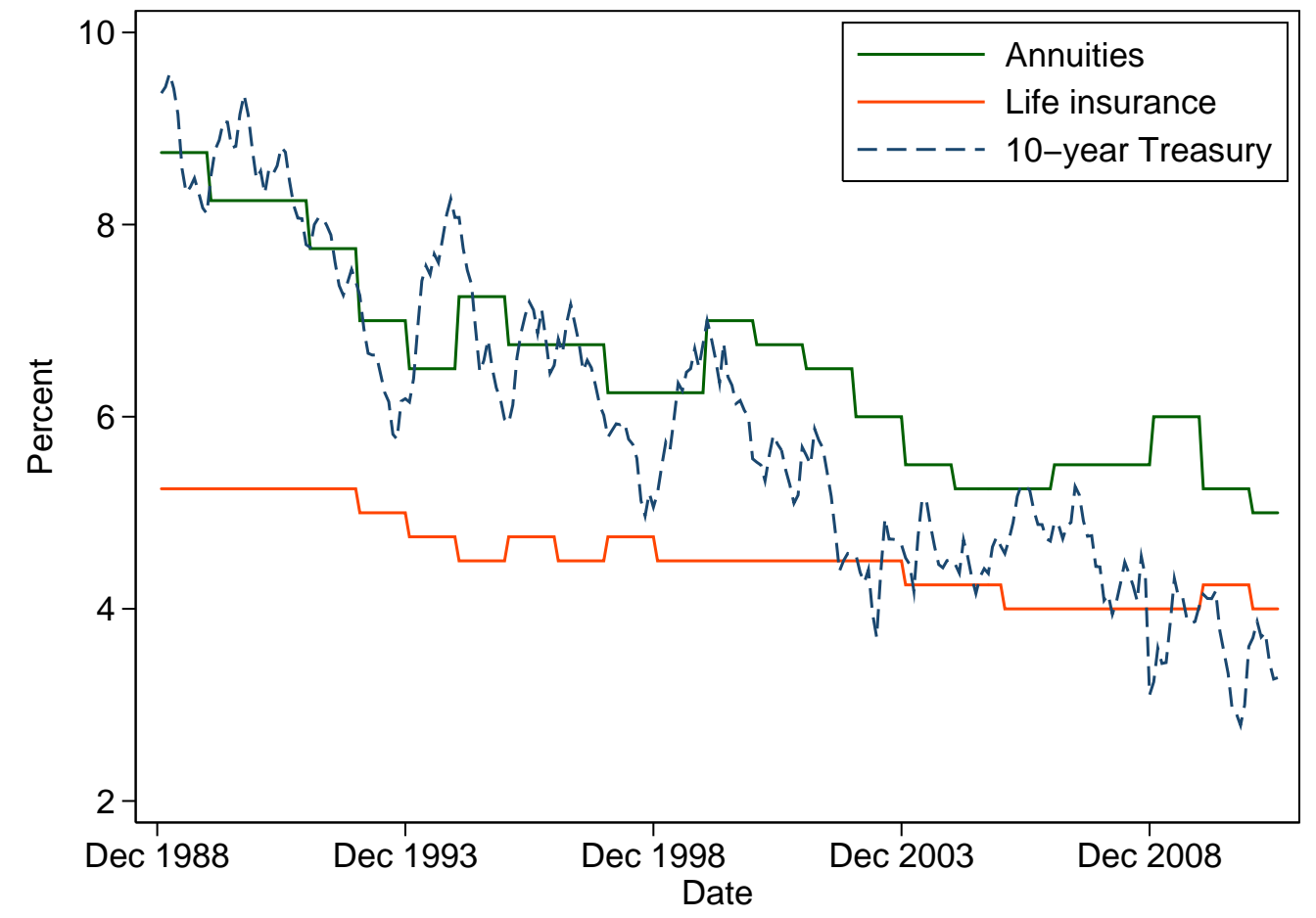

Figure 5: Discount Rates for Annuities and Life Insurance

This figure reports the discount rates used for statutory reserve valuation of annuities and life insurance, together with the 10-year zero-coupon Treasury yield. The monthly sample covers January 1989 to July 2011. 
Term annuities

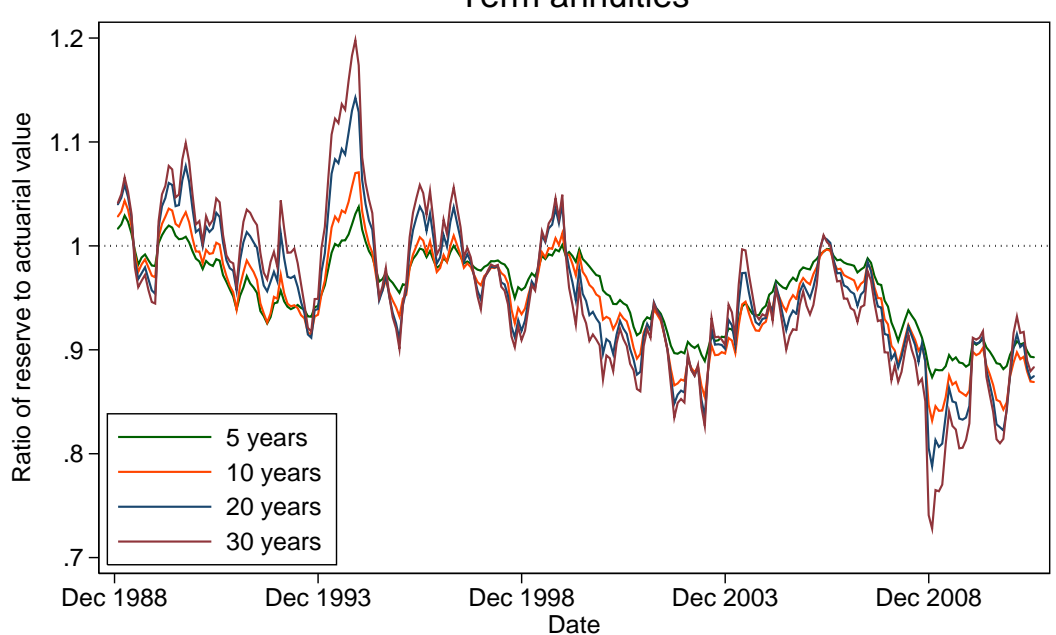

10-year guaranteed annuities
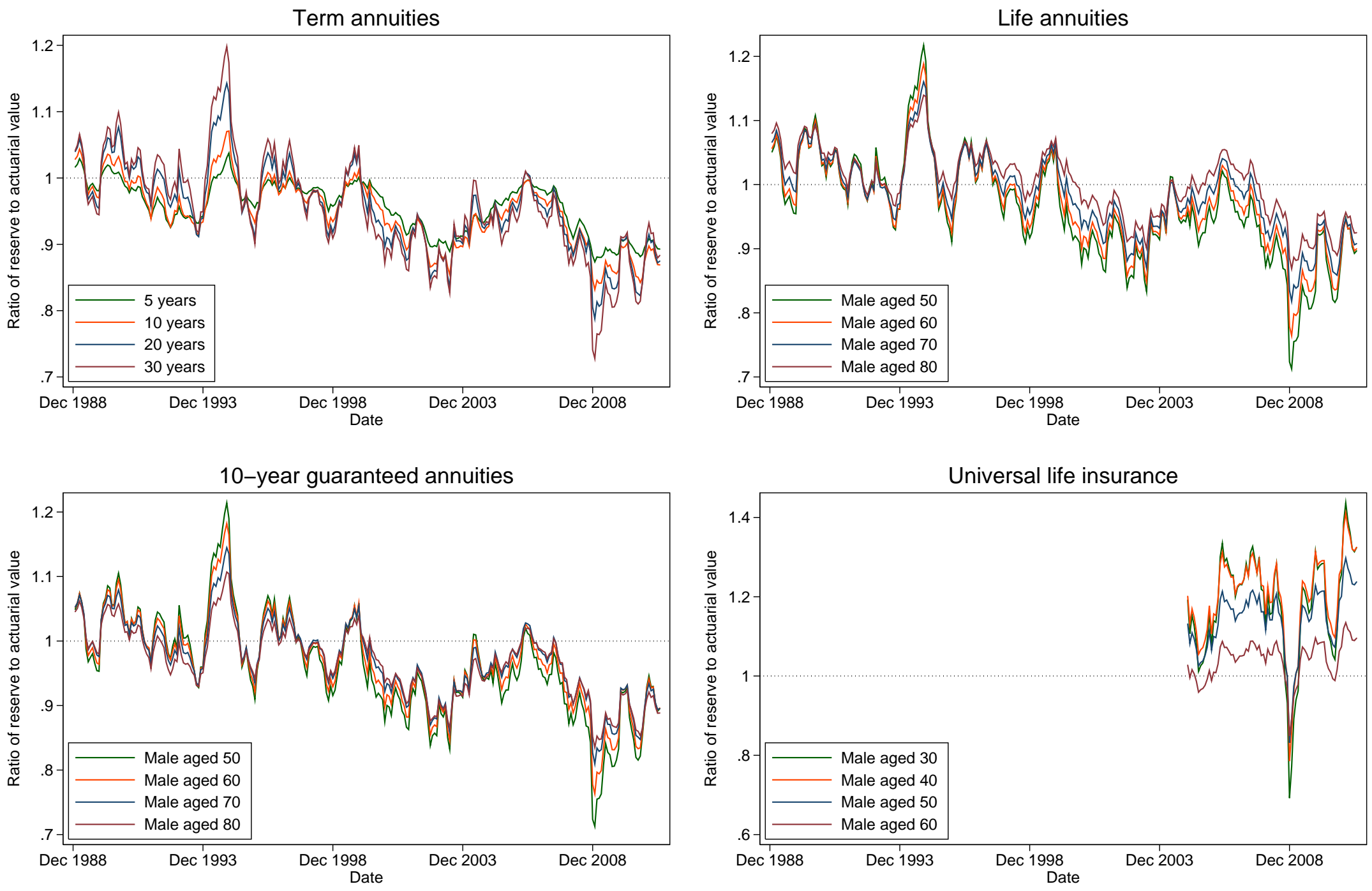

Figure 6: Reserve to Actuarial Value for Annuities and Life Insurance

The reserve value is based on the appropriate loaded mortality table from the American Society of Actuaries and the discount rate from Standard Valuation Law. The actuarial value is based on the appropriate basic mortality table from the American Society of Actuaries and the zero-coupon Treasury yield curve. The monthly sample covers January 1989 to July 2011 for annuities and January 2005 to July 2011 for life insurance. 


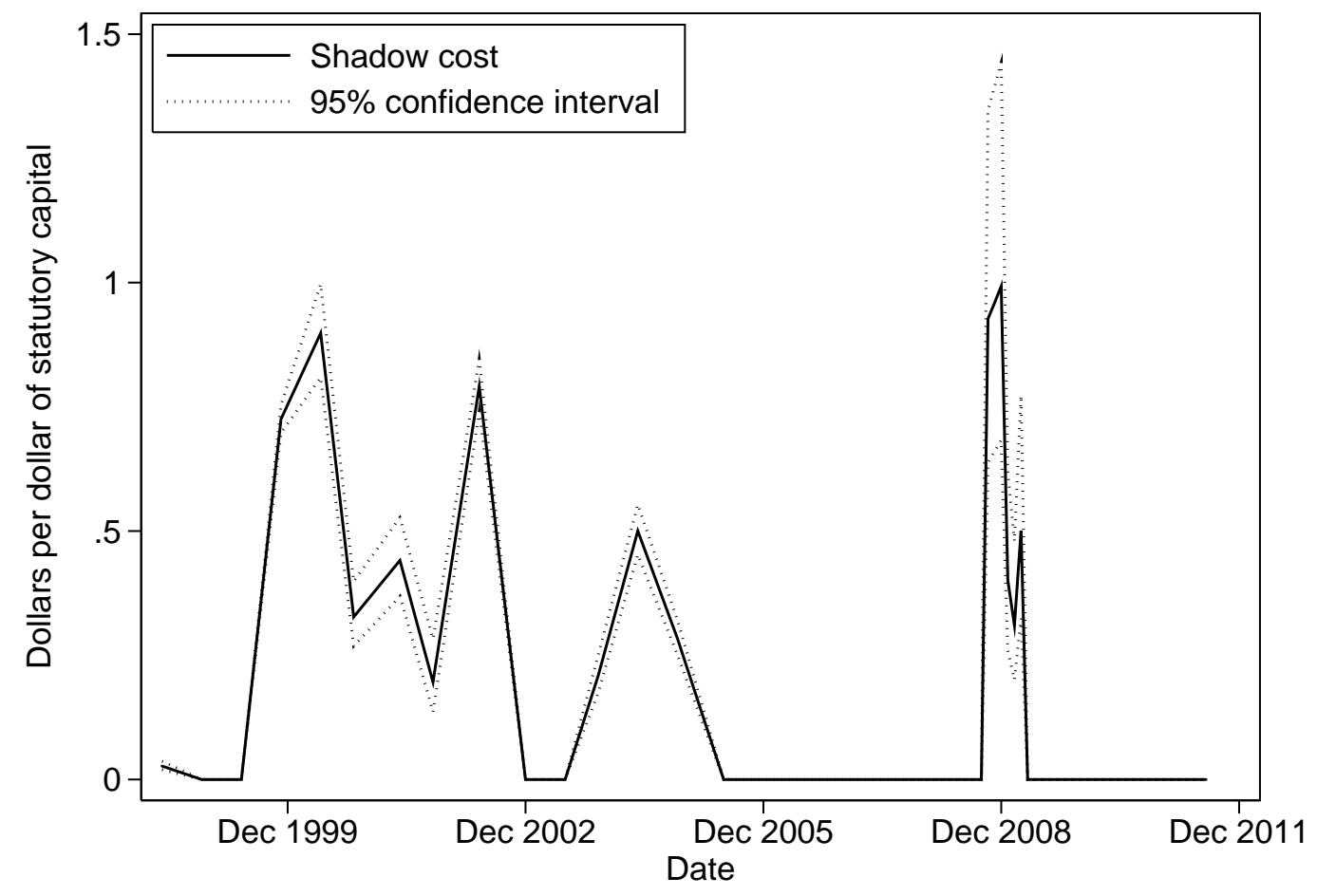

Figure 7: Shadow Cost of Capital

This figure reports the shadow cost of capital for the average company, implied by the estimated model of insurance pricing. The 95 percent confidence interval is based on robust standard errors, clustered by insurance company, type of policy, sex, and age. The sample covers life insurers with an A.M. Best rating of A- or higher from May 1998 to July 2011. 